\title{
Reintroducing "the" Scientific Method to Introduce Scientific Inquiry in Schools?
}

\author{
A Cautioning Plea Not to Throw Out the Baby with the Bathwater
}

\author{
Markus Emden $^{1}$ (D)
}

Accepted: 14 April 2021 / Published online: 13 May 2021

(C) The Author(s) 2021

\begin{abstract}
There are some crucial critiques on scientific inquiry and "the" Scientific Method in current science education. Recent research literature is replete with arguments against inquiry's legitimacy to be included in science classes, and it has even been abandoned from the Next Generation Science Standards. Critics of scientific inquiry in schools blame it to be a caricature of authentic inquiry suffering from five shortcomings: (1) knowledge becomes desocialized from its generative contexts, (2) scientific inquiry in schools suggests methodological monism favoring (3) a primacy of experimentation, (4) which portrays scientific inquiry as a knowledge automaton (5) raising an illusion of determination with regard to the generation of knowledge. This article argues for a reorientation of scientific inquiry in schools tentatively embracing "the" Scientific Method anew since critics appear not to sufficiently consider that scientific inquiry operates differently in schools from science. It will be shown that most critiques can be defused when untangling such an illegitimate mix-up of science proper with school science. It will be argued that current (and recent) descriptions of how science generates knowledge lack authoritative validity and should be fundamentally revisited. "The" Scientific Method will be shown to be a valid idealization that can serve as a frame of reference for introductory science classes. Still, it is understood that science education needs to extend beyond "the" Scientific Method if it is to prepare for science-related careers.
\end{abstract}

\section{Why Not Scientific Practices - a Kind of Disclaimer}

When the USA's National Research Council (NRC) decided to revise their National Science Education Standards (NRC, 1996), a committee was charged with developing and defining a framework for what would come to be the Next Generation Science Standards (NGSS Lead States, 2013). The committee suggested a three-dimensional Framework for K-12 Science Education (NRC, 2011) to serve as guiding light through teaching science — the dimensions are as follows: (1) Scientific and Engineering Practices (subsequently

Markus Emden

markus.emden@phzh.ch

1 Zurich University of Teacher Education, Lagerstrasse 2, 8090 Zurich, Switzerland 
referred to as Practices) - outlining prototypical modi operandi in science; (2) Crosscutting Concepts - highlighting those ideas that most scientific disciplines share and which, therefore, serve to interconnect the disciplines; (3) Disciplinary Core Ideas - summarizing the most crucial content in individual science disciplines that each student should be familiarized with when leaving secondary school. The 2011 Framework suggests reflecting the teaching of science in terms of these three dimensions as it understands scientific knowledge (1) to result from deliberate interventions of scientists with nature, (2) to depend on an interconnected knowledge from different scientific disciplines, and (3) to be defined by a more focused scope in one specific discipline. Choosing teaching content, thus, should consider (1) in how far students can learn about the generation of scientific knowledge from it, (2) how it connects to a more general perspective of all sciences, and (3) how central it is to understanding a single scientific discipline. This orientation was meant to discourage a mere cumulation of uncoordinated facts which - at worst - would not give a coherent picture of how science develops and works.

Just like with the National Education Standards (NRC, 1996), the Framework (NRC, 2011) resonated globally and quickly came to be regarded a universal point of reference for international science education. This is especially true for the Practices that came to substitute for the former Content Standard "Science as Inquiry" (NRC, 1996) which had been adapted in science curricula throughout the world to outline how students should learn about knowledge generation in the sciences (Baur et al., 2019; Emden, 2011). Therefore, the innovative Practices were met with curiosity; the Framework considers these Practices prototypical and central to scientific epistemology:

1. Asking questions (for science) and defining problems (for engineering)

2. Developing and using models

3. Planning and carrying out investigations

4. Analyzing and interpreting data

5. Using mathematics and computational thinking

6. Constructing explanations (for science) and designing solutions (for engineering)

7. Engaging in argument from evidence

8. Obtaining, evaluating, and communicating information

(NRC, 2011, p. 42)

In light of the Practices' elevated status, ${ }^{1}$ this article needs clarification why it chooses to deemphasize them. In their stead, this article will (seemingly anachronistically) prefer referring to scientific inquiry as a frame of reference for these reasons: (1) scientific inquiry has a long-standing tradition as well as a firm theoretical foundation in the philosophy of science (Dewey, 1938; Kosso, 2009; Popper, 1959/2008; Radder, 2009) and in science education (DeBoer, 2006; Lampkin, 1951; Schwab, 1960a); (2) scientific inquiry has been serving as an international frame of reference in science education for decades and continues to do so outside the USA (Abd-El-Khalick et al., 2004; Baur et al., 2019;

\footnotetext{
1 I am cautious and aware of the Practices' normative powers, which culminate in frequent rejection notes from scientific journals that seem to overstate the theoretical legitimacy of an, at least, underreferenced frame of reference (see below). While I welcome innovative ideas addressing the important and immensely complex content of scientific epistemology in science education, I wish these to stand the test of theoretical consideration.
} 
Emden, 2011) - not least in the Programme of International Student Assessment (PISA: Organisation for Economic Co-Operation and Development [OECD], 2000, 2003, 2006, 2009, 2013, 2016, 2019), (3) the current Practices claim to be reflective and inclusive of scientific inquiry (Bybee, 2011; Michaels et al., 2008). Scientific inquiry has been the topic of theoretical deliberation since the 1910s (e.g., Dewey, 1910a, b) — it has sprung from a philosophical question rather than from pragmatism. It was intended to account for the inner workings of epistemology in science, not just to facilitate teaching. While the second of these goals certainly is a legitimate one, it does not sufficiently explain why science education should switch from an explanatory concept (scientific inquiry) to a predominantly prescriptive one (Practices) — is this not a step into the wrong direction? The Practices' origins, theoretical, and philosophical underpinnings remain somewhat unclear. They were not included in the Committee Charge when preparing the Framework (cf. NRC, 2011, p. 16) - who, then, has decided they were needed? Osborne (2011) argues for the Practices' introduction as a means to translate the ways how scientists generate knowledge more easily into the classroom; prior to this, scientific inquiry had been interpreted increasingly fuzzy so that no uniform teaching approach had substantiated (cf. Barrow, 2006; Furtak et al., 2012b). He claims that Practices conveyed more clearly the expected outcome of teaching in terms of student activity (cf. Osborne, 2014). Yet, as far as the selection and wording of the Practices are concerned, neither Osborne (2011, 2014), nor the Framework (NRC, 2011), nor its supporting comments (e.g., Bybee, 2011) provide sources from which the Practices derive. Osborne backs each Practice as early as 2011 with research findings from science education and extends this literature in 2014; yet, this appears almost like an "ex post facto" justification of the individual Practices without attending to the comprehensive list. The Practices, in the beginning, appear like a deliberate canon that has been agreed on in an undisclosed manner.

This leaves room for questioning the overall tableau's justification: why are there eight differentiated Practices and not nine or ten - i.e., may we be sure that the Practices are necessary and sufficient? What about observing, categorizing, and comparing - are these irrelevant practices or are they understood to be contingent in another Practice? Why does "obtaining, evaluating, and communicating information" (NRC, 2011, p. 42) form one combined Practice instead of making up three distinct practices - i.e., may we be sure that each crucial practice receives the attention it deserves?

Reasonable though the Practices appear - Osborne (2011, 2014), after all, quotes ample evidence for each of them - in "concert" they seem to lack the kind of theoretical authority that scientific inquiry cherished from philosophy of science (Jackson, 1969; Kaufmann, 1959) and from science itself (Alberts, 2000; Mach, 1917). And while the Practices strive to supersede scientific inquiry, they fail to clearly demarcate themselves from it - in some instances even claiming to be inclusive of scientific inquiry (Michaels et al., 2008, p. 34). Popularly, the Practices are regarded to signify roughly the same as scientific inquiry (García-Carmona, 2020) even if they could be charged with their very own potentials (Ford, 2015).

Reading the Practices, it needs a very alert mind to keep track of why, e.g., "asking questions" today should denote a Practice and why it might no longer be considered an aspect of scientific inquiry. This observation is corroborated by Furtak and Penuel (2019) who report that practicing teachers have repeatedly challenged them about the distinction between Practices and scientific inquiry. Scientific inquiry has - for a very long time - been considered fit to build a bridge from school into research science; why should this have changed just because of the Practices' advent? 


\section{Scientific Inquiry in Science Proper ${ }^{2}$}

Traditionally, Francis Bacon is credited with introducing systematic inquiry into natural phenomena with his Novum Organum Scientarium: "Simili modo, \& occulta Naturæ magis se produnt per vexationes Artium, quam cum curu suo meant"3 (Bacon, 1620/1752, liber I, aphorism XCVIII, 96). It was meant to supersede the prevailing scientific paradigm of the day that had been borrowed from Aristotle's (fourth century BCE) Organon which favored rational logic over empirical testing. Bacon's inductive method probably is one of the earliest codifications of how scientific knowledge can be systematically generated by putting questions at nature. ${ }^{4}$ German chemist Justus von Liebig — himself a defender of hypothetico-deductive inquiry (Liebig, 1865) — passionately rejected Bacon's primacy over scientific method (Liebig, 1863) and credited Leonardo da Vinci instead with being the founding father of an empirical scientific methodology: "La sperienza non falla mai, ma sol fallano i vostri giudizi promettendosi di quella effeto tale che in e nostri experimenti causati non sono"5 (Leonardo da Vinci, 1478-1519, f. 154 r-a, 417-r). Either way, it is no coincidence that an empirical scientific method, and essentially scientific inquiry, should come into being during the Renaissance, i.e., during the transition to the Age of Reason (Enlightenment): "It [scientific inquiry] was a successful competitor to the belief that all knowledge was revealed by God through chosen messengers. As Galileo and others found out, the idea that an individual could come to know the world through the use of the senses and reasoning was not popular with the church and governments of the age. Yet this way of thinking about ourselves led to intellectual, spiritual, political, and economic freedom" (Finley \& Pocoví, 2000, p. 49). ${ }^{6}$

2 I will be using Kant's term "science proper" (1783/1883, p. 138) to distinguish the realm of disciplinary science from that of science education - these alternative terms are dismissed for the given reasons: authentic science (see below for ambiguous meanings of authenticity), genuine science (as school science should not be implied to be "fake science"), academic science (as science is practiced validly and professionally outside academia)

3 " [... S ]o the Secrets of Nature are better got out by the Torturing of Arts, than when suffer'd to take their own course." (translation from Shaw, 1733, p. 394); i.e., nature must be coaxed ("tortured") into revealing her secrets by asking the right questions - left to her own, she will reveal nothing.

4 "Science is an interrogation of nature but nature can only respond in the way the question is asked." (Selby, 2006a, p. 9 attributing the quote to British chemist and philosopher Michael Polanyi). The idea of an interrogation mirrors Bacon's "Torturing of Arts" and can be found in Kant's Critique of Pure Reason: "Reason, in order to be taught by nature, must approach nature with its principles in one hand, [...] and, in the other hand, the experiments thought out in accordance with these principles - yet in order to be instructed by nature not like a pupil, who has recited to him whatever the teacher wants to say, but like an appointed judge who compels witnesses to answer the questions he puts to them." (Kant, 1781/1998 p., 109, emphasis added). German philosopher and pedagogue Theodor Litt (1959, p. 67) shares the sentiment: "Es ist ja durchaus nicht so, daß die naturwissenschaftliche Erkenntnis die Natur, so wie sie sich unmittelbar der Anschauung präsentiert, einfach abschriebe. Die tritt mit einer bestimmten, methodisch präzisierten Frage an sie heran und erhält von ihr naturgemäß nur diejenige Antwort, die dieser Frage korrespondiert.“ ["Indeed, it is not the case that scientific inquiry simply transcribes nature as it presents itself to the immediate perception. Inquiry addresses nature with a definite, methodically specified question and can, naturally, only receive that response which corresponds the question." - my translation]

5 "Experience is never at fault; it is only your judgment that is in error in promising itself such results from experience as are not caused by our experiments.“ (translation from McCurdy, 1923, p. 56)

6 In a similar vein, German physicist and philosopher Carl Friedrich von Weizsäcker characterizes empirical inquiry as a tool of liberation: “To experiment means to exert power uposn nature." (Weizsäcker, 1952, p. 199) and "The experiment is an exercise of power in the service of knowledge. It makes it possible, conversely, to apply knowledge in the service of power. Its benefits and dangers are the benefits and dangers of power." (Weizsäcker, 1952, p. 209) 
The mere recourse to formulating questions and systematized answer-seeking does not make inquiry a scientific enterprise - other scholarly disciplines, e.g., the humanities or philosophy, do the same (Osborne, 2011); science's primary claim to its idiosyncratic kind of inquiry is that its statements of knowledge are empirically testable (Selby, 2006a, b) and, thus, are fallible in principle. Lampkin (1951, p. 21) provides a list of characteristics of scientific inquiry in which fallibility and empiricism are codefined by their antonyms: scientific inquiry is "sceptical, rather than dogmatic" (i.e., it starts in a question) and "probable, rather than necessary" (i.e., it is fallible); it is "public, rather than private" (i.e., it is empirical).

Inquiry's feature of fallibility has been emphasized by philosopher Karl R. Popper who introduced the principle of falsification to a theory of scientific inquiry and did away with Bacon's Method of Induction (Popper, 1959/2008, p. 4): "Now it is far from obvious, from a logical point of view, that we are justified in inferring universal statements from singular ones, no matter how numerous; for any conclusion drawn in this way may always turn out to be false: no matter how many instances of white swans we may have observed, this does not justify the conclusion that all swans are white."

Popper claimed that scientific inquiry necessarily was hypothetico-deductive in nature as the construction of new knowledge always needed to build on pre-existing knowledge — this notion has become known as "theory-ladenness of knowledge" (Lederman, 2007): "Knowledge cannot start from nothing - from a tabula rasa - nor yet from observation. The advance of knowledge consists, mainly, in the modification of earlier knowledge" (Popper, 1960/1985, p. 55). Pure induction, therefore, is an impossibility and even discovery - from an information processing point of view — is hypothetico-deductive in nature ${ }^{7}$ (Lawson, 2002). Speaking of experimentation - one of the most prominent manifestations of scientific inquiry (Kirschner, 1992) - Wong and Hodson (2009, p. 120) come to conclude from their interviews with established research scientists that "no theory-independent experiments are possible. Rather, every experiment is conducted within a particular theoretical matrix, which governs the investigator's perception of the problem(s), determines the experimental design, and influences the interpretation of the results."

Scientific inquiry in science proper then needs to be understood as extending the existing knowledge basis by systematically testing our understanding of nature's mechanisms. This is achieved by trying to predict its behavior in a controlled situation and check if the predictions apply.

\section{Alternative Approaches to Scientific Inquiry}

However, this reading of scientific inquiry should not be understood as an absolute truth. It needs to be stressed that scientific inquiry signifies a Western - alternatively quipped Eurocentric, Euro-American, or Western modern (Zidny et al., 2020) - approach to making sense of nature and has itself been contested. Scientific inquiry

\footnotetext{
7 The restriction to this approach has not gone uncontested. Feyerabend (1993) famously challenged the idea of a uniform method of inquiry claiming that "anything goes" in science: science's ways of inquiring into nature were so ingenuous and idiosyncratic that they defied a generalizing description. This seems to be supported by Kuhn's (1962b) differentiation between normal and revolutionary science in which the latter capitalizes on breaking with generalizing paradigms — "thinking outside the box" might prevail and, thus, negates the absoluteness of a pattern.
} 
like all epistemological approaches feeds from the culture it derives from (cf. Bang \& Medin, 2010) - a culture that is predominantly male and white.

In contrast, feminist approaches to science and inquiry challenge this "norm" insofar that they expect different questions to be investigated from a women's perspective. It has been claimed that just restricting oneself to the dominant perspective of the day makes objectivity an implausibility (Haraway, 1988), so that current science per se might not deliver on its core requirement (objectivity). In what has been termed "feminist standpoint theory," the rationale is that only by taking the perspective of the underprivileged or marginalized (in this case: women) is it possible to recognize relevant fields of research as these typically arise from the needs of the underprivileged (Harding, 1992). In other words, male white scientists could not possibly identify all the questions relevant to mankind (which includes women) as they lack the experience of what it means to live as a woman (cf. Harding, 1987, 1992). This does not exclude men from contributing to feminism, though, as long as they start their thought from women's lives (Harding, 1992). Some researchers claim that a feminist theory of inquiry would result in increased care and rigor of investigations (Harding, 1992). The overall mechanisms of inquiry would not necessarily be that much different, but feminist inquiry could ensure, e.g., that testing cosmetics on animals would not be restricted to male rats whose estrus cycle does not complicate matters (Harding, 1987; this appears, in light of a substantial proportion of the addressed clientele for these products also exhibiting complicated estrus cycles, cynical to say the least), crash-test-dummies would be redesigned to account for different demands from women's anthropometry (cf. Linder \& Svedberg, 2019), etc. Certainly, scientific inquiry does not actively prevent these kinds of research, but at the same time, it does nothing to ascertain that they are considered regularly (Harding, 1992). Instead, the female rat's estrus cycle was eliminated as a confounding variable (Harding, 1987) and the current design of the crash-test-dummy is more likely witness to a dated role-image of women who would not drive cars but prepare their husbands' dinners (where using a female dummy is mandatory, it is — tellingly — assigned to the passenger seat only: Linder \& Svedberg, 2019).

In a comparable manner, indigenous or native science approaches emphasize the highly involved nature of the researcher with their objects of study. Unlike the make-believe of Western science, indigenous and native sciences do not claim that researchers could detach themselves from nature to achieve objectivity (cf. Cajete, 2004). On the contrary, they attest to the researcher always being a part of the object of study. Indigenous (Zidny et al., 2020) or native science (Bang \& Medin, 2010; Cajete, 2004, 2005) is, just like feminist science, situated knowledge (cf. Haraway, 1988); i.e.,it originates in a definite locale to attend to definite issues of the locality (Bang \& Medin, 2010; Zidny et al., 2020). It is a science that is very much problem-oriented and feeds from traditional experience of First Nations (Bang \& Medin, 2010; Cajete, 2005). In Principle, it might operate much like Western scientific inquiry - starting from observation and indulging in experiments or employing models (Black Elk, 2016; Cajete, 2004) — but it is defined, at its core, by a very different mindset from Western Science: "we are all related" (Black Elk, 2016, Cajete, 2005). This results in a practice of science that respects its "object" as a discursive partner and not as some passive externality that needs to be taken care of (Bang \& Medin, 2010). At the same time, it requires indigenous or native scientists to be more holistic in their approaches (Cajete, 2004; Zidny \& Eilks, 2020) as they realize that they are not communing with some detached entity but that they are affecting their own states of being by doing research. In this respect, indigenous and native sciences are expected to complement the Western approach to science (Zidny \& Eilks, 2020). 
These two examples of alternative approaches to generating knowledge in science might suffice to show that we must not be misled into thinking that attending to the Western image of scientific inquiry is sufficient for science education. Yet, seeing that alternative approaches could on principle agree on some of the mechanisms of how to generate knowledge, it makes scientific inquiry a necessary topic of science education from which alternative approaches may be developed. Seeing that scientific inquiry has often been accused of neglecting its agents as crucial shapers of scientific knowledge (see below), it is noteworthy that this critique rarely has extended beyond the privileged, Western white frame of reference. The remainder of this argument will be restricted to this frame of reference, too, fully aware of the additional limitations this incurs. Then again, disproving critiques should optimally tread on the same grounds as the critics do.

\section{Scientific Inquiry vs. "the" Scientific Method}

Scientific inquiry - in science proper - denotes the natural sciences' epistemological approach to extend their body of knowledge and has prominently been defined by the NRC (1996) embracing a concurrent, paralleled understanding of scientific inquiry in schools:

Scientific inquiry refers to the diverse ways in which scientists study the natural world and propose explanations based on the evidence derived from their work [i.e., scientific inquiry in science proper]. Inquiry also refers to the activities of students in which they develop knowledge and understanding of scientific ideas, as well as an understanding of how scientists study the natural world [i.e., scientific inquiry in schools].

Inquiry [in both understandings] is a multifaceted activity that involves making observations; posing questions; examining books and other sources of information to see what is already known; planning investigations; reviewing what is already known in light of experimental evidence; using tools to gather, analyze, and interpret data; proposing answers, explanations, and predictions; and communicating the results. Inquiry requires identification of assumptions, use of critical and logical thinking, and consideration of alternative explanations. (NRC, 1996, p. 23)

Since its introduction to the discourse by John Dewey (1910b) as a philosophical theory how science - in general - extends its knowledge, scientific inquiry has - in schools frequently (and mistakenly; Tang et al., 2009) been equated with hands-on science (Hodson, 2014), experimentation (Lederman et al., 2014), or "the" Scientific Method, a stepwise heuristic scientists assumedly employ in their research (Ioannidou \& Erduran, 2021; McComas, 1996; Woodcock, 2014). Probably, it is this distorted understanding of scientific inquiry in schools that the Practices aim to transcend ("the specific practice of inquiry": Michaels et al., 2008, p. 34). Scientific inquiry in schools then needs to be understood as an interpretation of scientific inquiry in science proper for science classes.

Both, school's narrowing of scientific inquiry to experimentation and its assumedly linear process structure have repeatedly been criticized (Harwood et al., 2002; Osborne, 2011; Reiff et al., 2002; Selby, 2006b; Woodcock, 2014). Rather, scientific inquiry in schools should be understood as embracing a multitude of discrete methods which do not fit one unified process pattern (Furtak \& Penuel, 2019) - this "alternative" reading that to some extent has motivated the Practices' (NRC, 2011) introduction ironically is faithful to the NRC's (1996) earlier definition. 
It appears scientific inquiry in schools usually has been represented as an inflexible, rigid rendering of the actual processes of scientific inquiry in science proper ("the" Scientific Method). In addition, scientific inquiry in schools has unreasonably been confined to dealing with experimentation. However, e.g., a scientific observation must equally start in a "question" in order to distinguish observation from mere retinal registration. Observing an individual means to deliberately focus on one or few aspects of its behavior; thus, observations presuppose a principal prior knowledge of the object to be observed and requires the observation to be a decidedly deliberate operation, as opposed to, e.g., "seeing" (cf. Woodcock, 2014). This constrains the observers' perception and, thus, limits potential observations (Medawar, 1990; Windschitl et al., 2008) and eventual answers to the original question. So, in principle, observation can be retold analogously to an experiment in scientific inquiry just as modelling could be described along the lines of the same simplified process.

Scientific inquiry in schools usually needs to differentiate between these perspectives: scientific inquiry as a way to teach science (inquiry teaching), scientific inquiry as a way to learn science (inquiry learning), scientific inquiry as a content for teaching science (Crawford, 2014; Furtak et al., 2012a). This distinction carries some import: e.g., accounts of inquiry teaching often suggest generalized teaching approaches that are modelled on the processes of inquiry (e.g., Bell et al., 2005; Harwood, 2004b) but need not necessarily take mechanisms of student learning into account; addressing inquiry learning focuses on student-activating, constructivist learning arrangements that emphasize the empirical nature of inquiry and scientific reasoning or use scaffolds that reflect the processes of inquiry (e.g., Lazonder, 2014) but need not rely on personal instruction; lastly, bringing inquiry as a teaching content into the classroom largely refers to the justification of the content and its added value for students' formation (e.g., Chinn \& Malhotra, 2002, or Bildung: Sjöström, 2013; Sjöström \& Eilks, 2020) but needs not provide ideas of how to teach and how learning might be advanced. These three perspectives cannot be viewed to be completely independent of each other - underlying each of them is an idea of what scientific inquiry is (content-perspective). Its characteristics shape how inquiry-labelled teaching approaches distinguish themselves from, e.g., projectbased teaching. The same is true of scientific inquiry's influence on concepts of student learning - as a rule, inquiry learning will be triggered by a question and followed by some form of empirical investigation which, however, needs not be strictly scientific. Nonetheless, it is useful to differentiate these perspectives when addressing issues of scientific inquiry as they orient an argument.

\section{Five Critiques on Scientific Inquiry in Schools}

Much of the criticism on scientific inquiry in schools focuses on the aspect of scientific inquiry as a teaching content and can be summarized in five generalized critiques on scientific inquiry in schools:

(1) Scientific inquiry in science proper builds on scientific attitudes and motivation; scientific inquiry in schools disregards the motivation and driving forces of the acting researcher. Scientists bring their belief systems and personal interest into a dialectic exchange when investigating; theirs is not a business of mere "'record[ing]' phenomena somehow 'given' directly in observation" (Gooding, 1991, p. 309). Oftentimes these "private process[es] of creation" in an inquiry are overshadowed by the "public process[es] of validation" through reporting (Selby, 2006a, p. 10) so that the scientists' 
very personal contributions may go unnoticed. Traditional models of scientific inquiry fail to acknowledge the reflective practice that scientists actually go through when performing and evaluating their investigations (Yang et al., 2007). This critique includes accusing scientific inquiry in schools of conveying an inadequate picture of scientists doing much of their work alone; in reality, science progresses from engagement with fellow scientists and discussions in peer groups (e.g., Olesko, 2015; Woodcock, 2014; Yang et al., 2007); students have rarely been acquainted with these discursive elements of inquiry (Miller et al., 2018). In summary, scientific inquiry in schools is said to acquiesce to a desocialization of knowledge from its generative determinants (all the more so, if one considers the perspectives of alternative approaches to science (see above)).

(2) Scientific inquiry in science proper commands an armament of methodological approaches (exploratory, inductive, associative, etc.); scientific inquiry in schools predominantly conveys "the" Scientific Method which denotes a "fairly rigid, definite series" of "the steps in scientific reasoning" (Gagné, 1965; p. 10). Its prominence in, e.g., textbooks has made it a virtual myth according to which all research scientists adhere to this prescribed sequence (McComas, 1996, 2020b; Woodcock, 2014). Although actual ways of scientific inquiry may be "few in number and capable of formulation" (Schwab, 1960b, p. 1), school science appears to have decided on spreading a single, i.e., hypothetico-deductive approach which implies a methodological monism that defies authentic inquiry.

(3) Scientific inquiry in science proper flexibly combines different practices of investigation (observation, modelling, experimentation, simulation, etc.) depending on the object of inquiry (Ioannidou \& Erduran, 2021); scientific inquiry in school restricts itself almost invariably to experimentation (Lederman et al., 2014). To some degree, this favoring of a single practice is mirrored in reality as there seems to be a tendency to primarily fund experimental research (Andersen \& Hepburn, 2016; Strasser, 2012). If scientific inquiry is addressed in science education, it most often is approached by means of the experiment - may the perennial question of students at the science room's threshold bear witness to this: "Will we do an experiment today?" A marked reliance of experimental procedures in communicating science, be it in Christmas Lectures (Emden \& Gerwig, 2020; James, 2007), be it on YouTube, probably contributes to this perceived primacy of experimentation.

(4) Scientific inquiry in science proper relies firmly on prior content knowledge; scientific inquiry in schools trivializes the importance of content knowledge and scientific reasoning in favor of a supposedly decontextualized method. School's approach to scientific inquiry has frequently been dubbed "a hands-on but not a minds-on activity" (Hofstein \& Kind, 2012, p. 202) — informally also referred to "as hands-on-minds-off" with students "manipulating equipment but not manipulating ideas" (Lunetta, 1998, p. 250). The basic assumption is that students should be doing something manually (DeBoer, 2006) as this change of mode and active involvement could contribute to their learning. Most often an awareness that this activity could help students to solve problems is not raised (Crowell, 1937). The mandatory inclusion of prior knowledge in problem solving processes such as these (Hume, 2009) is often downplayed in favor of communicating supposedly generalizable and transferable skills (Donnelly, 2005). It is by this abstraction from a given situation, in which scientists need to exert their flexibility, that the processes of scientific inquiry are expected to unfailingly produce new knowledge (Chinn \& Malhotra, 2002; Dunbar, 2000; Harwood et al., 2005). In 
summary, scientific inquiry in schools is accused of being portrayed as a knowledge automaton that would arguably provide answers on a no-input-basis. ${ }^{8}$

(5) Scientific inquiry in science proper is characterized by dead-ends, unforeseeable twists and turns and does not usually unfold straightforwardly; scientific inquiry in schools most often suggests a linear, non-iterative course of investigation (Ioannidou \& Erduran, 2021). Investigations in science proper are carried out by human beings who bring their individual biographies and personalities into it (cf. desocialization of knowledge) - for this reason, scientific inquiry cannot really be portrayed as a wholly objective or dispassionate enterprise (Grinnell, 2013) and, thus, cannot be expected to run smoothly through all its steps. "The idea of a selfcontained procedure (disconnected from theories or scientific models) with orderly steps and much of the epistemological complexity stripped away is, unfortunately, a useful fiction. [... It] is a rigid procedural text-but not a way of thinking" (Windschitl, 2004; p. 505). This "useful fiction" has essentially been designed for the classroom allowing an investigation to be completed within the time frame of a single science lesson (Windschitl et al., 2008) while iteratively revisiting certain elements in an investigative course is the norm in science proper (Harwood et al., 2002). Irrespective of its pragmatic advantages, it needs to be understood that the linear process model of scientific inquiry in schools supports an illusion of determination.

Most of these critiques rely to some degree on an (mostly implicit) understanding of the authenticity of science education. To complicate matters, authenticity itself is a contended concept (Burgin, 2020; Martin et al., 1990; Murphy et al., 2006) and can be approached from several directions (Anker-Hansen \& Andrée, 2019): (1) authenticity arising from a comparison with professional science, especially considering inquiry practices $(\approx$ cultural authenticity; Murphy et al., 2006, pp. 231-232), (2) authenticity being defined by its relevance to the students' world ( $\approx$ personal authenticity; Murphy et al., 2006, p. 232), (3) authenticity as pertaining to the reality of school (be it with reference to curricula or to the forms of interaction in classes). The first two perspectives are the ones most often addressed in recent research literature (Anker-Hansen \& Andrée, 2019).

In sum, this makes scientific inquiry a head term for a plethora (not only one) of scientific methods (Hodson, 1998; Ioannidou \& Erduran, 2021; Wilson, 1974) — describable through prototypical professional practices - which depend on content knowledge and the psychological make-up of a researcher. To address the issue of scientific inquiry authentically in schools challenges the teacher to understand what scientific inquiry means in science proper, how it can relate to the students' world, and how it can harmonize with a culture of school. Little wonder that contesting interpretations may prevail.

The remainder of the article will refer to scientific inquiry in schools from the perspective of its being a teaching content which needs to be modelled on professional practices

\footnotetext{
8 The five critiques on scientific inquiry in schools cannot claim to be disjunct. They overlap to some degree - and possibly nowhere more than between the twin-critiques of desocializing knowledge and knowledge automaton. Interpreting scientific inquiry as an automaton necessarily implies that social and "humanizing" aspects of the endeavor have been deleted. Nonetheless, both these critiques each have their legitimacy - while desocializing knowledge turns against neglecting the importance of prior knowledge and conviction of the acting researcher which eventually channels research into an ordered process, knowledge automaton primarily addresses an assumedly inherent feature of the process that disregards the process's flexibility to spontaneously adapt to changing circumstances. As the process and the actor cannot be viewed completely independent of each other, an overlap results.
} 
(Yang et al., 2007) - these need not be identical with the NGSS's Practices. Put differently: The article investigates, in how far scientific inquiry can be implemented culturally authentically in schools. This endeavor will need to refer to the student perspective now and again. The focus of this, however, will not be how inquiry facilitates learning (i.e., inquiry learning) but how student potentials actually limit an authentic inclusion of a complex content such as scientific inquiry.

\section{Five Tentative Replies to Critiques on Scientific Inquiry in Schools}

The following paragraphs will discuss how the five critiques on scientific inquiry in schools all rely on an unfortunate mix-up of scientific inquiry in science proper and in schools, respectively. Realizing that both institutions are to some degree at odds with each other in their approaches to scientific inquiry - regarding the conditions from which they feed and in which they operate (e.g., experts $v$ s. novices, rich theoretical background $v s$. "clean slate"/naïve conceptions; self-direction vs. externally motivated) - must lead to the conclusion that the one (science proper) cannot serve as a comprehensive, valid measure stick for the other (school). If the Practices were instrumental to solve this issue, they would be most welcome but, as it is, they cannot claim to check any of the critiques.

\subsection{Scientific Inquiry in Schools vs. Desocialization of Knowledge}

This section will discuss in how far scientific inquiry in schools acquiesces to a desocialization of knowledge from its generative contexts. It will do so by focusing on selected personality traits of researchers that affect research such as beliefs, knowledge, hunches, and collaborations. Other equally valid aspects, such as, e.g., historical and social embeddedness of scientific research (e.g., Lederman, 2007), are disregarded for the moment. To understand these would require even more factual knowledgefrom students ${ }^{9}$ than realizing that their own lack of content knowledge puts them at a disadvantage compared to research scientists. Attending primarily to researchers' personalities might be understood to seek out the most relatable aspect for students that could be addressed in classes to soften the critique.

\subsubsection{Desocialization in the Steps of "the" Scientific Method}

Analyzing scientific inquiry with regard to the steps of "the" Scientific Method suggests that scientific inquiry in schoolsrarely refers to the inquirers and their personal contribution (Selby, 2006a). This proves to be a massive shortcoming since neither observations, nor questions and hypotheses, nor design of an inquiry, nor its analysis can unfold before a conceptual void (cf. Williams, 1968) and, thus, neither can be imagined without a reflecting person going through these steps. Observation requires the inquirer to recognize "both that

\footnotetext{
9 They would need to find answers to questions such as the following: In how far was Sputnik and The Race to Space decisive for scientific development and which role did conflicting ideologies and politics play in this? Why is stem-cell research not allowed in some countries? Why did the Catholic Church forbid Galileo Galilei to spread his defense of heliocentrism? Why is it predominantly (male) Western scientists who are awarded Nobel Prizes in science?
} 
something is and what it is" (Kuhn, 1962a, p. 762) - Alexander Fleming ${ }^{10}$ did not dismiss his famous petri dish as just "a contaminated culture plate" as the rest of his colleagues might have done (Gillies, 2006, p. 54) but he realized that there was something special about this culture and what made it special: a natural antibiotic at work. This, essentially, made him remark "That's funny." (Gillies, 2006, p. 52) instead of an also understandable "Urgh, that's disgusting."

Questions in inquiry need to be "testable" (Wilcox et al., 2015) or "scientific" (Bevins $\&$ Price, 2016) to ultimately guide the inquiry process (Lederman et al., 2014). They need to derive from theory as inquiry through, e.g., experimentation would be impossible otherwise: "[The theoretician] must have formulated his question as sharply as possible. Thus, it is he who shows the experimenter the way. [...] Theory dominates the experimental work from its initial planning up to the finishing touches in the laboratory." (Popper, 1959/2008, p. 90). An experiment must not only be performed but it must be thought of in advance (cf. Faraday, 1827, p. iii); i.e., it needs to be distilled into a question which needs prior knowledge and the actual interest of a researcher; without this it cannot come to fruition.

Tentative answers to these questions are usually called hypotheses. Their actual role in scientific discovery is very much disputed (cf. Woodcock, 2014) as they are sometimes only formulated in retrospect when drafting a research article (Medawar, 1990) or when applying for a grant (Wong \& Hodson, 2009). They are suspected to have been overly emphasized in school depictions of "the" Scientific Method (Harwood et al., 2002; Ioannidou \& Erduran, 2021; Woodcock, 2014).

This might be due to too strict and formal a definition of an hypothesis which, therefore, makes it a hard-to-learn construct which needs special devotion and considerable lesson time - understanding a hypothesis to mean "an unambiguous prediction of the measurable correlations between two definite variables" cannot be achieved easily. One might step back, though, from requiring a hypothesis to spell out a functional claim between two variables ("I expect the rate of reaction to increase as temperature increases by a factor 2 for each $10 \mathrm{~K} . "$ - causal hypothesis (Wenham, 1993)) in favor of "articulating an expectation" (Harwood, 2004a, p. 45); "[n]or need hypotheses always be precisely formulated. It is perfectly legitimate simply to look for confirmation (or not) of a hypothesis as vague as ' $\mathrm{x}$ may have an effect' [predictive hypothesis (Wenham, 1993)]" (Hodson, 1988, p. 56). These expectations need not even be made explicit to guide inquiry (Ayala, 1994, p. 212), but: they need to exist because "[w]ithout at least a tentative solution to the problem in mind, there is nothing to direct attention: it is impossible to decide what action is required or what evidence is likely to be relevant" (Wenham, 1993, p. 234).

Likewise, the choice of inquiry method relies on prior knowledge and, thus, is theoryladen. Scientists do not choose a tool blindfolded and it has become a truism in science that the extent of our practical capabilities shapes our modus operandi: "I suppose it is tempting, if the only tool you have is a hammer, to treat everything as if it were a nail" (Maslow, 1966, p. 15). Without an intimate knowledge of the methodological (and technical) armament of a discipline, one cannot accomplish much in researching it - the competent researcher knows when and why a particular method will help them in their research. They will not record a ${ }^{13} \mathrm{C}-\mathrm{NMR}$ either when they investigate carbon-free structures or when they are not interested in a molecule's architecture. They will not go mechanically through

10 Awarded the 1945 Nobel Prize for Physiology or Medicine together with Ernst Boris Chain and Howard Walter Flores "for the discovery of penicillin and its curative effects in various infectious diseases". (Nobel Foundation, 1945) 
a set course of investigations as the accomplished researcher will know which technique will yield which kind of answer.

Not to overstress science's dependence on prior positive knowledge, one needs to be aware that not everything in a scientific investigation needs to be planned explicitly. Occasionally, scientists will opt for unorthodox, more intuitive approaches ("acting on a hunch") which will make a difference. Yet, even then they will have a tentative, maybe not explicit expectation connected to deviating from protocol - these 'hunches' in science are essential and are by no means "blind guesses." By definition, the "hunch" "springs from a wide knowledge of facts [...]. It is a process of creative thought" (Platt \& Baker, 1931, p. 1975): Nobel-laureate Barry Marshall ${ }^{11}$ deliberately ingested Helicobacter pylori to show its causing peptic ulcers (Hellstrom, 2006; Marshall et al., 1985; Pincock, 2005). He only decided to undergo this self-experiment after experiments on his chosen model system (two pigs) had not resulted in them developing ulcers or gastritis (Meuler, 2012). His conviction to be right was well founded in prior studies on the correlation between peptic ulcers and bacterial cultures found in human stomachs (Marshall \& Warren, 1984). ${ }^{12}$

Lastly, analyzing and interpreting the outcome of an inquiry necessarily need to be related to theory as "science is a cumulative subject in which each scientist must build on the work of others" (Ayala, 1994, p. 239). Data analysis is conducted in the interest to optimally answer the guiding research question - this requires reference of new insights to existing knowledge and their combination. This is not a disinterested process in which researchers excuse themselves to the bleachers: e.g., they have to choose which data to use and which to dismiss in their argument - contrary to his own assertions, Millikan ${ }^{13}$ did not include all measurements in his report (Franklin, 1989; Hintikka, 2005). He was not intentionally dishonest but he was so convinced of his findings that most deviating measurements appeared like measuring error to him.

In order to relate the new to the known, analogy building is a frequent strategy for research scientists (Dunbar, 2000), which requires a wealth of prior knowledge to draw from. Novices to science, such as school students, could hardly draw an analogy for the sheer lack of suitably analogous concepts. They are, too, at a disadvantage when experimenting in schools as they lack the rich theoretical background that could help them to make sense of their readings and observations. This is probably a compelling reason why "cookbook" exercises or confirmation labs still feature so prominently in science classes.

\subsubsection{Different Goals of Scientific Inquiry Emphasize the Researcher's Role Differently}

It follows that scientific inquiry develops in full before a coherent theoretical backcloth. This aspect appears to be not trivial and limits the potentials of scientific inquiry in schools

\footnotetext{
11 Awarded the 2005 Nobel Prize for Physiology or Medicine together with J. Robin Warren "for their discovery of the bacterium Helicobacter pylori and its role in gastritis and peptic ulcer disease". (Nobel Foundation, 2005)

12 While I have a strong "hunch" that there are notable discoveries (maybe not so much inquiries — cf. French, 2006) that result from tinkering with apparatus ("Let's see what happens if ...") or twiddling the dials ("Have you tried measuring x instead of y?"), I could not positively identify cases from the literature. There are some hints to be found in Platt and Baker (1931), though. A virtual absence of explorative "tinkering" from research literature is most likely attributable to the standards of reporting (see below). As the "hunch" is admitted to be working frequently in science research by a third of the replicants to Platt and Baker (1931), another 50\% claiming they had occasionally been assisted by hunches, it appears to play a crucial, albeit silent role in scientific inquiry in science proper.

13 Awarded the 1923 Nobel Prize for Physics "for his work on the elementary charge of electricity and on the photoelectric effect" (Nobel Foundation, 1923)
} 
tremendously as opposed to in science proper. Or, rather: The awareness of this limitation must remind us that scientific inquiry in schools is different from scientific inquiry in science proper ${ }^{14}$ : "[...] there is a fundamental distinction between the goal of science education and the goal of science. The goal of science is to discover new knowledge. The goal of science education, in contrast, is to help students build an understanding of old knowledge, or to put it more accurately, what is the consensually agreed scientific explanation" (Osborne, 2019, p. 1282). This means that scientific inquiry in science proper is very much about the process, which is unimaginable without its processor who reassembles extant knowledge. Scientific inquiry in schools has been more concerned with the process's output which has been cleared of its processor by reporting (see Section 6.2) and which has not typically stressed the cumulative nature of scientific knowledge. ${ }^{15}$ This does not mean that for the sheer lack of prior knowledge we should not try to teach the processes of scientific inquiry - we must, however, respect that scientific inquiry in schools cannot evolve as freely as scientific inquiry in science proper ${ }^{16}$ and, thus, we must not expect the impossible from it.

At the same time, it must be stressed that science proper operates on somewhat comparable premises as school science. One of research's primary motivations is to find out the unknown; i.e., the research scientist does not know everything in advance and has to explore terra incognita, too. Research scientists themselves, thus, can be understood to be students "in nature's school" (cf. Gooding, 1985). This is not to veil the crucial difference, though: researchers are expert students in nature's school and - even in cutting-edge science - still can rely on infinitely more positive scientific knowledge and experience than the common school student.

\subsubsection{Desocialization Through Neglect of Epistemic Community}

On a different note, one must realize that scientific research is not a solitary engagement - much of science's progress results from work in teams (Dunbar, 2000; Lederman, 2007; McComas \& Nouri, 2016; Russ, 2014; Selby, 2006a) or at least building on research done by others (Ayala, 1994). Meaning and practice of scientific inquiry are themselves socially negotiated (Manz et al., 2020; Windschitl, 2004) and manifest in distinctive epistemic communities which signify "group[s] of people with a shared repertoire, mutually engaged in a shared activity [... with the ...] primary goal [of] the creation and warranting of knowledge" (Feldman et al., 2009, p. 447). Within these groups, scientific inquiry is practiced and communicated idiosyncratically between experts - e.g., very much centering

\footnotetext{
14 "Remind" is the crucial term here as the basic idea is not novel by far (Crawford, 2014; Gaskell, 1992; Gengarelly \& Abrams, 2009; Hume, 2009; Kapon et al., 2018; Kirschner, 2009; Russ, 2014).

15 e.g., competing atomic models coexist as virtually unrelated pieces of knowledge for students; they are not necessarily told that the different models have been developed from each other (cf. Justi \& Gilbert, 2000).

16 "While fellows explained that the student research projects were quite similar to that of their own research, they also indicated some clear differences. For example, in contrast to the high school projects which were focused in general on known concepts or topics, with exception of the bio-technology projects, the fellows suggested that their own research was not constrained by a known topic or concept but rather at the edge of the unknown. Each fellow described his or her work as an ongoing process of developing a research question and extending their work as necessary to arrive at convincing evidence for or against an original hypothesis or research objective. Furthermore, the fellows' [sic] described their own research development as less guided than the high school students"” (Gengarelly \& Abrams,2009, p. 82)
} 
on single members of a group (hubs-and-spoke) or very much networked between many researchers (web) (Feldman et al., 2009). Knorr Cetina (1999) argues for distinctive epistemic cultures between domains so that inquiry approaches between science disciplines may differ to some degree.

Scientific inquiry in schools does not adequately mirror this social aspect of generating knowledge (Erduran \& Dagher, 2014; Kapon et al., 2018) and, thus, represents the inquiry process undercomplex as it "kills off" the need for expert negotiation (Tweney, 2006; Yang et al., 2007). This is not to discredit social interactions in schools or cooperative learning and meaning making. These are necessary ingredients to develop students into active science-doers instead of receivers of facts, as is explicating a connection to their lived experience (cf. Miller et al., 2018). However, theirs is not (yet) and instantiation of pre-scientific discourse which should build on shared theoretical frames of reference, technical language, and meet certain requirements for proof. Unless students learn to relate their experience in this rather formalized way of interaction, their discourse cannot be considered science-in-the-making but, equally important, engaging in the art of social intercourse.

\subsection{Scientific Inquiry in Schools vs. Methodological Monism}

Nobel-laureate Peter Medawar ${ }^{17}$ (1990) challenged the understanding of how science is actually done in his article "Is the scientific paper a fraud?" He criticized that the ubiquitous structure of scientific papers delineating a determinate sequence to generate knowledge (question-hypothesis-sample, method and design-results-analysis-conclusion) had become tantamount to "the" Scientific Method - "in the public eye" one should add. Science proper, so he claimed, worked in much more tangled ways and seldomly did the reported structure align with the actual processes of inquiry. His criticism has been taken up and reinforced repeatedly (e.g., Clough, 2000; Howitt \& Wilson, 2014; Osborne et al., 2003).

It needs to be understood that research articles usually undergo peer-review which capitalizes on this premise: specialists in a field with much expertise in content and method rate their colleagues' research regarding fitness for publication. Reviewers are the gatekeepers of today's science and are responsible to "encourage innovative thinking [... and, simultaneously, for ...] weeding out false ideas" (Ayala, 1994, p. 239). This process of gatekeeping admittedly only pertains to "normal science" and somewhat hinders "scientific revolution" (Kuhn, 1962b), ${ }^{18}$ but as revolutions are arguably fewer than processes of normal inquiry, one is well advised to keep in mind that scientific reasoning is "governed by a set of normative criteria set by the scientific community" (Osborne, 2014, p. 181). These implicit criteria are essentially the key to the structure of the research article (Howitt \& Wilson, 2014; Medawar, 1990) and the subsequent misrepresentation of "the" Scientific Method in scientific inquiry in schools (Howitt \& Wilson, 2014). Obeying the rules will get you published even if

\footnotetext{
17 Awarded the 1960 Nobel Prize for Physiology or Medicine together with Frank Macfarlane Burnett "for discovery of acquired immunological tolerance" (Nobel Foundation, 1960)

18 When Marshall and Warren tried to publish their findings of a bacterium that caused ulcers with The Lancet in 1984, the journal encountered serious difficulties in recruiting reviewers that would not outright reject the novel notion of bacteria resisting the stomach's acid environment (Pincock, 2005).
} 
it is distorting the actual processes of your discovery ${ }^{19}$ : "It needs to be stressed that the report of an experiment appearing in, say, a scientific journal is a highly artificial product which, far from giving an unproblematic account of work in the laboratory, is a form of narrative" (Cantor, 1989, p. 160).

Scientists presumably know how to read these reports having composed several themselves. They are not looking for an adventure story but for an account that links a body of existing knowledge to new insights plus an intimation of how they can check the claims. Thus, science proper has adopted a corset as tight as the paper-structure for purely economic reasons: to make themselves understood quickly. The scientific paper serves a rhetoric function (Cantor, 1989); it does not claim to give a naturalistic account but a functional rendition that is to advise and inform other scientists whose time is precious. It mainly is "inside information presented to insiders" - it is not primarily a means to communicate science to outsiders. This suggests that research scientists employ the structure of the article as a frame of reference that allows for cursory reading - it has become a tacit compromise, which to follow is to everybody's benefit (Wong \& Hodson, 2010). Therefore, that artificial structure is superimposed on actual inquiry processes and peer-reviewers insist on obeying it. Even if the actual inquiry processes have not run exactly like the courses laid out in the article structure, it is remarkable to realize that their majority can be retold in terms of this structure. So, there appears to be a grain of truth in "the" Scientific Method after all, as far as logic and spinning a narrative yarn are concerned: "Generally, there is a method of inquiry that scientists follow to obtain information on the model(s) under investigation. Most know this as the 'scientific method.' However, so often this method is oversimplified and given too much precedence in science teaching" (Spiece \& Colosi, 2000, p. 34).

Speaking from a positivist point of view, the portrayal of science's ways of generating knowledge in scientific papers certainly is - at the very least - misleading or romanticizing: science proper does not (or at least: not always) work like this. Then again, the most pronounced dissent against this misrepresentation appears not to originate with science proper. Insinuations that the scientific paper paints a detailed and realistic picture appear to come from the sidelines, from an informed but outside "lay" public (e.g., teachers, science educators, science afficionados). Which is more in a need of being corrected: The structure that has been working for its intended readership for decades or the interpretations of the interested outsider?

The scientific paper supports an image of science generating knowledge hypotheticodeductively - which might be argued to be an inclusive paradigm of other approaches (cf. Lawson, 2002). Scientific inquiry in schools has concentrated largely on this approach and neglected inductive methods (Bacon, 1620/1752) or methods of abduction (Peirce, 1903/1974). Introductory science teaching may encourage students to explore or to "discover" (Bruner, 1973; Saunders-Stewart et al., 2012). This is understood to pave the road for subsequent inquiry learning. Discovery-learning, however, has been criticized largely for its learning ineffectiveness (Kirschner et al., 2006; Mayer, 2004; Sweller et al., 2007) and has lost much of its former luster. School books favor hypothetico-deductive characterizations of how science generates knowledge (cf.Blachowicz, 2009) which might be a

19 See Howitt and Wilson (2014) for an example of Watson and Crick's discovery of the DNA's double helix. Watson and Crick were awarded the 1962 Nobel Prize for Physiology or Medicine together with Maurice Hugh Frederick Wilkins "for their discoveries concerning the molecular structure of nucleic acids and its significance for information transfer in living material" (Nobel Foundation, 1962). 
function of teachers' understanding that induction cannot progress without rich conceptual knowledge and that, thus, induction is largely inaccessible to school science.

\subsection{Scientific Inquiry in Schools vs. Primacy of Experimentation}

There is more than one scientific method in scientific inquiry's quiver (cf. NRC, 1996). Nonetheless, scientific inquiry in schools has often been equated with hypothesis testing by experiment (Furtak \& Penuel, 2019; Hodson, 1998; Ioannidou \& Erduran, 2021; Lederman et al., 2014; Reiff et al., 2002; Windschitl, 2004) — and often falsely so (Abrahams \& Millar, 2008; McComas, 1996, 2005). Experimentation has been understood to be the quintessential empirical activity of science (Kirschner, 1992; Manz et al., 2020), and thus, the laboratory has become a defining aspect of science classes (Hofstein \& Kind, 2012; Hofstein \& Lunetta, 2004). While the fundamental assumptions about experimentation's value may be true, they have led to a distortion of how science works: "And, although experimentation is an important feature of science, it is not the defining feature." (Osborne, 2015, p. 16).

This appears to be a critique that cannot easily be dismissed as it is true. Inquiry teaching has virtually become synonymous with "doing a lab" which in turn often came out as hands-on-minds-off (Crowell, 1937; DeBoer, 2006; Hofstein \& Kind, 2012; Osborne, 2015; Wee et al., 2007). Other methods of inquiry such as observation or modelling have too often been disregarded even if modelling could be argued to be a more fundamental method on which even experimentation builds (Manz et al., 2020; Windschitl et al., 2008). The NRC (1996) had emphasized the multi-method character of scientific inquiry in its standards and, thus, had tried to advice for a balanced and more authentic representation of scientific inquiry in schools. It obviously failed, but the Practices do not appear to make amends in this respect as they make only modelling obligatory and veil other methods relying on the generalized term "investigations." In order to adjust an image of scientific inquiry in schools, probably, still more support for teachers was needed to understand how, e.g., models and modelling might be incorporated into science classes (e.g., Gilbert, 2004; Gogolin \& Krüger, 2018; Justi \& van Driel, 2005) and how (and which) different methods of scientific inquiry interact in actual research.

\subsection{Scientific Inquiry in Schools vs. Knowledge Automaton}

The personality of the research scientist is probably a decisive factor for progress in scientific inquiry (Grinnell, 2013; Selby, 2006a). They have a passion for what they do, and they command a wealth of prior experience that advises them when something curious comes up (Alberts, 2000; Gooding, 1991; Hume, 2009; Wilson, 1974). Even their perception differs from that of the unskilled as "discovering a new sort of phenomenon is necessarily a complex process which involves recognizing both that something is and what it is" (Kuhn, 1962a, p. 762). This flash of genius that feeds from the research scientist's body of knowledge was famously quipped by nineteenth century chemist Louis Pasteur: "Dans le champs de l'observation le hasard ne favorise que les esprits préparés." ${ }^{20}$ It is the basis for serendipitous discovery which is essential for science proper (Reiff et al., 2002) but, essentially, is not teachable (Brown \& Kumar, 2013). Serendipity is one outward sign that

\footnotetext{
20 "In the field of observation fortune favours only the prepared mind." (translation from Gillies, 2006, p. 54).
} 
research processes do adhere to a rigid schedule and, at the same time, that the processes are inherently flexible to a remarkable extent to allow for spontaneous adaptations such as, e.g., unplanned iterations, omissions, extensions/bypasses. This flexibility needs someone to exploit it so that the researcher's personality factors majorly in the equation.

Science education that aimed at the kind of scientific inquiry that is practiced in science proper would have to teach creativity, curiosity, skepticism, and spontaneity. This might be addressed from a Bildung point of view (cf. Sjöström \& Eilks, 2020) which is not yet a very frequent perspective of science education which most often concentrates on content (cf. Sjöström, 2013).

\subsection{Scientific Inquiry in Schools vs. Illusion of Determination}

A process that is inherently flexible to adaptation cannot ultimately be captured in a single determinate structure that accounts for each example from research science. Scientific inquiry in science proper probably cannot travel a one-way street, and researchers might get side-tracked now and again. This appears to be at odds with the depiction of scientific inquiry in schools. Simplifying the processes of scientific inquiry, e.g., into a determinate sequence, is on the one hand a necessity of teaching (Osborne, 2011), on the other hand has it served as a means of self-illusion (Finley \& Pocoví, 2000; Windschitl, 2004). Significant detrimental effects of this development need to be considered: "One important implication of our analysis is that simple inquiry tasks may [...] foster a nonscientific epistemology in which scientific reasoning is viewed as simple, certain, algorithmic, and focused at a surface level of observation" (Chinn \& Malhotra, 2002, p. 190). In other words, a simplification can only carry so far and must not be overstressed.

A justification for the simplification appears to read thus: Scientific inquiry has been prominent in schools for at least since the days of Sputnik (Barrow, 2006; Crawford, 2014; DeBoer, 2006). It has been understood as modeling a process of science to which students need to be introduced (Gower, 1997). Already Schwab (1960a, 1966) suggested that students should be introduced to scientific inquiry in a stepwise fashion - he suggested a rather coarse distinction into problem, method, and answer, which has proven to be perennial as numerous suggestions to scaffolding scientific inquiry in schools fall back on Schwab's suggestion (e.g., Bell et al., 2005; Herron, 1971). Apart from this structure being congruent with that of most research articles, it can be brought to match with models from instructional psychology such as the Scientific Discovery as Dual Search model (SDDS: Klahr \& Dunbar, 1988). Many other, more finely tuned suggestions to structure processes of knowledge generation in school science can be subsumed under these three steps (see Fig. 1 and Emden \& Baur, 2017; Emden \& Sumfleth, 2016; see also: Woodcock, 2014).

Even the NGSS's Practices can be grouped under the three headings "question," "investigation," "answer." This requires a sequence be inscribed into some Practices (sequentiable Practices) and interpreting some of the Practices as being fundamental and therefore underlaying the other practices (i.e., developing and using models; using mathematics and computational thinking; obtaining, evaluating, and communicating information). One can argue that, e.g., asking questions already is an act of scientific modeling (which variable to choose, which relations to assume, which approach of investigation to choose etc.) that embraces aspects of mathematical/computational thinking (do we expect a positive or negative relation) that need to be communicated to fellow students and/or the teacher (Emden \& Baur, 2017). Other non-sequential suggestions to describe scientific inquiry in schools 
— such as the inquiry wheel (Harwood, , 2004a, b; Robinson, 2004) — show a comparable proneness to be included in the three-stepped distinction introduced by Schwab (1960a).

In the end, this suggests that from a functional point of view neither scientific inquiry in schools, nor "the" Scientific Method, nor the Practices are contradictory of each other or incommensurable - all agree that there needs to be a question (which might rise from preceding observation) that can be empirically investigated/tested and that the generated evidence needs to be related back to an existing body of knowledge. The issue fundamentally arises over the authenticity of scientific inquiry in schools and its ontological interpretation: is it a book of rule or is it not?

\subsection{Implications of Reviewing the Critiques on Scientific Inquiry in Schools}

Science proper's approach to scientific inquiry necessarily is different from school's approach: researchers can enter on scientific inquiry's potentially infinite degrees of freedom as they are well prepared to tackle the issue of theory-ladenness of scientific knowledge (Duschl, 2008; Hodson, 1996, 1998; Truran, 2013) - school students are not. Therefore, research scientists can play variations of a fundamentally shared theme (cf. Dunbar, 2000) - school students cannot. The genius of research science flourishes where innovation builds on the work of others, where, using a dance metaphor, new figures are created - school students need to learn the basic moves first ${ }^{21}$ and, thus, need a prescriptive, simplified abstraction of scientific inquiry (much like the "slow-slow-quick-quick-slow"rhythm in our inner ears when tangoing).

Research scientists understand scientific inquiry as a frame of reference (cf. Tibbetts, 1977) where school students - and their teachers (Ioannidou \& Erduran, 2021) — misinterpret it as a book of rule ("the" Scientific Method). This, however, is not likely to change by consistently changing the name of the dance but presumably by investing more effort into making students realize that what they learn are the basic moves and not science proper. The actual critique with regard to "the" Scientific Method should not be on introducing it but leaving it at that (cf. Spiece \& Colosi, 2000). So, instead of rejecting even the remote idea of a consensual frame of reference for scientific inquiry in schools (Alexakos, 2010; Brown \& Kumar, 2013; Furtak \& Penuel, 2019; Hodson, 1998; Lederman et al., 2014; McComas, 1996; Osborne, 2011; Rudolph, 2005; Selby, 2006b; Williams, 2008; Windschitl, 2004) or wishing for its removal from science classes (Jenkins, 2007; Woodcock, 2014), more efforts need to be put into identifying such a shared frame of reference and then filling it with life.

Science education must not reject the idea of scientific inquiry in schools just because it does not ideally match the professional practices in science proper. Much of the above critique could be alleviated if science education could agree that scientific inquiry in schools or "the" Scientific Method should not be read as a book of rule (see knowledge automaton, illusion of determination, methodological monism) but rather as a frame of reference that provides orientation while preserving individual degrees of freedom (cf. Tibbetts, 1977). The latter aspect is salient for scientists who practice scientific inquiry in science proper — they must not be ruled in by a tight methodological corset; they have learned to find and

21 This, admittedly, is true for beginning scientists who need to be introduced into scientific inquiry by their academic peers. However, these practices should probably not be the model for scientific inquiry as a content which more likely should be designed on basis of expert practice. Besides, there appears to be no comprehensive introduction to scientific inquiry for colleges and universities - apart from variations on the already criticized Scientific Method from textbooks (e.g., Demtröder, 2015). 


\begin{tabular}{|c|c|c|c|c|c|c|c|c|c|c|c|c|}
\hline \multirow{3}{*}{$\begin{array}{c}\text {,the' Scientific } \\
\text { Method } \\
\text { (Windschitl, 2004) } \\
\\
\text { Dewey (1910a) }\end{array}$} & \multirow{3}{*}{$\begin{array}{c}\begin{array}{c}\text { Making } \\
\text { observations }\end{array} \\
\begin{array}{l}\text { Occurrence } \\
\text { of difficulty }\end{array}\end{array}$} & \multicolumn{3}{|c|}{ (1) Question } & \multicolumn{6}{|c|}{ (2) Investigation } & \multirow{3}{*}{$\begin{array}{c}\text { (3) Answer } \\
\text { Drawing conclusions }\end{array}$} & \\
\hline & & \multirow{2}{*}{\begin{tabular}{|c|}
$\begin{array}{c}\text { Developing a } \\
\text { question }\end{array}$ \\
$\begin{array}{c}\text { Definition of } \\
\text { difficulty }\end{array}$ \\
\end{tabular}} & \multicolumn{2}{|c|}{ Constructing hypothesis } & \multicolumn{4}{|c|}{ Experimenting } & \multicolumn{2}{|c|}{ Analyzing data } & & \\
\hline & & & $\begin{array}{r}\text { Occurren } \\
\text { a sugges } \\
\text { explanati } \\
\text { possib } \\
\text { solutio }\end{array}$ & 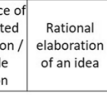 & \multirow{2}{*}{\multicolumn{7}{|c|}{ (experimental) Corroboration of an idea and formation of a concluding belief }} & \\
\hline $\begin{array}{l}\text { Schwab (1966), } \\
\text { Herron (1971) }\end{array}$ & \multicolumn{4}{|c|}{ Problem } & & & & & & & & \\
\hline Kempa (1986) & \multicolumn{4}{|c|}{ Perceive and formulate a problem } & $\begin{array}{c}\text { Designy } \\
\text { plan }\end{array}$ & \multicolumn{2}{|c|}{\begin{tabular}{|c|}
$\begin{array}{c}\text { Setting up } \\
\text { experiment// } \\
\text { execute }\end{array}$ \\
\end{tabular}} & \multirow[t]{2}{*}{$\begin{array}{l}\text { Measure, } \\
\text { observe, } \\
\text { record }\end{array}$} & \multicolumn{3}{|c|}{ Interpret and evaluate } & \\
\hline $\begin{array}{l}\text { Klahr \& Dunbar } \\
\text { (1988) }\end{array}$ & & \multicolumn{3}{|c|}{ Search hypothesis space } & \multicolumn{3}{|c|}{ Test hypothesis } & & \multicolumn{3}{|c|}{ Evaluate evidence } & \\
\hline NRC (1996) & & \multicolumn{3}{|c|}{ Asking a simple question } & \multicolumn{4}{|c|}{ Completing an investigation } & \multicolumn{3}{|c|}{ Answering the question } & Presenting results \\
\hline Lunetta (1998) & & \multicolumn{3}{|c|}{ Plan and design } & & & \multicolumn{2}{|c|}{ Perform } & \multicolumn{2}{|c|}{ Analyze and interpret } & & Apply \\
\hline Harwood $(2004 a, b)$ & Observing & \multicolumn{3}{|c|}{\begin{tabular}{|c|c|c|c|c|c|c|c|} 
Defining & Forming & Investiga & Articulating the \\
the & the & ting the & expectation \\
problem question & known & \\
\end{tabular}} & \multicolumn{4}{|c|}{ Carrying out the study } & \multicolumn{2}{|c|}{ Examining the results } & Reflecting on findings & $\begin{array}{c}\text { Communicating with } \\
\text { others }\end{array}$ \\
\hline $\begin{array}{l}\text { Bell, Smetana \& } \\
\text { Binns (2005) }\end{array}$ & & \multicolumn{3}{|c|}{ Question } & \multicolumn{4}{|c|}{ Method } & \multicolumn{3}{|c|}{ Solution } & \\
\hline $\begin{array}{l}\text { Hammann, Phan, } \\
\text { Ehmer \& Grimm } \\
(2008)\end{array}$ & & \multicolumn{3}{|c|}{ Forming hypotheses } & \multicolumn{4}{|c|}{ Planning experiments } & Analyzir & g data & & \\
\hline $\begin{array}{l}\text { Kipnis \& Hofstein } \\
\text { (2008) }\end{array}$ & & Identify problem & Formu & late hypothesis & & Design e & experim & & Gather and a & nalyze data & Draw conclusion & \\
\hline & & & king questi & & & $\begin{array}{l}\text { lanning an } \\
\text { invest }\end{array}$ & $\begin{array}{l}n \text { carryl } \\
\text { tigation }\end{array}$ & $\begin{array}{l}\text { ng out } \\
\text { s }\end{array}$ & $\begin{array}{r}\text { Analyzing and } \\
\text { da }\end{array}$ & $\begin{array}{l}\text { Interpreting } \\
\text { a }\end{array}$ & $\begin{array}{l}\text { Constructing } \\
\text { explanations }\end{array}$ & $\begin{array}{c}\text { Engaging in argument } \\
\text { from evidence }\end{array}$ \\
\hline NRC (2011) & & & & & & & Devel & oping and usi & ing models & & & \\
\hline & & & & & & Using $\mathrm{m}$ & nathem & atics and com & mputational thin & king & & \\
\hline & & & & & & btaining, & evaluat & ing and comn & municating info & mation & & \\
\hline Osborne (2014) & & Hypotl & thesis gene & eration & & Experi & imentin & & Evidence e & valuation & & \\
\hline & Orientation & & neeptualiza & ition & & & & Investigatio & & & Conclusion & Discussion \\
\hline Pedaste et al. (2015) & & Questioning & Hypoth & nesis generation & $\begin{array}{l}\text { Explo- } \\
\text { ration }\end{array}$ & $\begin{array}{c}\text { Obser- } \\
\text { vation }\end{array}$ & $\begin{array}{l}\text { Plan- } \\
\text { ning }\end{array}$ & $\begin{array}{l}\text { Experimen- } \\
\text { tation }\end{array}$ & $\begin{array}{l}\text { Data interpre- } \\
\text { tation }\end{array}$ & Analysis & & $\begin{array}{c}\text { Communi- } \\
\text { cation }\end{array}$ \\
\hline $\begin{array}{c}\text { Emden \& } \\
\text { Sumfleth(2016) }\end{array}$ & & Find ic & idea / hypo & thesis & & & Plan a & nd conduct ex & experiment & & $\begin{array}{c}\text { Conclude from } \\
\text { experimental evidence }\end{array}$ & \\
\hline
\end{tabular}

Fig. 1 "The" Scientific Method in contrast to several other suggestions for structuring how science generates knowledge (I give Windschitl (2004) as a source for "the" Scientific Method not because he supports the idea (on the contrary!) but because his choice of sequence is reflective of a multitude of coexisting definitions of "the" Scientific Method.)

productively exploit these degrees of freedom through previously amassing content and procedural knowledge (Bond-Robinson \& Stucky, 2005; Finley \& Pocoví, 2000; Hodson, 1996; Kirschner, 1992; Wieman, 2015).

\section{What Needs to Be Done? - an Agenda for Science Education Development}

A key problem of any description of scientific inquiry, "the" Scientific Method or Practices for schools appears to gnaw at their claims of validity already. It appears that hardly (if!) any of the suggested process structures of scientific inquiry has been developed with reference to practicing research scientists. ${ }^{22}$ There are few notable exceptions (Harwood, 2004a; Keeslar, 1945; Reiff et al., 2002; Wieman, 2015; Yang et al., 2007) - yet, even these mostly fail to encourage criticism on their suggested processes or to have their results validated by the same experts. Keeslar ironically finds: "There is a high degree of agreement among the research scientists of the University of Michigan as to what the elements of scientific method are. None of the fifty-four elements submitted tentatively for validation

22 This might be attributed to a conviction that, although research scientists are professionals at conducting research, they are not so competent in reflecting its inner mechanisms: "[...] most scientists tend to understand little more about science than fish about hydrodynamics." (Lakatos, 1978/1999, p. 62) 
in the questionnaire was rejected by the majority of the twenty-two judges. The opinion has often been expressed by scientific workers that there is no such thing as 'the scientific method'; yet for the twenty-two research scientists who judged the list of items critically in this study, the term does have a specialized meaning which can be expressed in term of general policies and steps of procedure in the solving of a problem" (Keeslar, 1945, p. 277). It should be noted that Keeslar (1945) suggests a rich and rather complex depiction of 54(!) elements of scientific method which, only later, he himself "boils down" to ten elements of scientific method for high-school students. The research scientists of his study might not have objected to the very detailed list, but we cannot be sure about their judgment on his simplification.

Critics of "the" Scientific Method most often come from science education (Alexakos, 2010; Furtak \& Penuel, 2019; Hodson, 1998; McComas, 1996; Windschitl et al., 2008) or philosophy of science (Feyerabend, 1975/1993; Gower, 1997; Haack, 1995; Rudolph, 2005; Woodcock, 2014) - at the same time, it is them who have come up with the descriptions of how science is done in the first place. Research scientists rarely speak out on scientific inquiry or "the" Scientific Method (Herron, 1971) — if they do (Alberts, 2000; Selby, 2006a, b; Wong and Hodson, 2009, 2010), they are admittedly not too fond of school's depiction.

\subsection{A Panel Expert Approach to Correcting Scientific Inquiry in Schools}

It appears that a description of the ways of science (way being translatable as $\mu \varepsilon \dot{\theta} \theta \delta$ os (method)) that could rest on an authoritative basis - i.e., being developed together with practicing professional scientists - might address some of the basic critiques on scientific inquiry in schools that critics claim to be essentially lies about scientific inquiry per se. This might well be done with an expert panel (cf. Chang Rundgren \& Rundgren, 2017; Kloser, 2014; Osborne et al., 2003) in which practicing experimental scientists could be encouraged to contribute their views regarding the five crucial critiques (see Table 1). Above this, they should be encouraged to relate how their research actually unfolds. If scientific inquiry in schools really defies cultural authenticity, the experts' opinions should be instructive in righting these misguided approaches. Feeding back results from such a panel to science educators and science philosophers could then serve to validate innovative descriptions for schools of how science generates knowledge. In addition, panelists should comment on these aspects that could steer scientific inquiry in schools into a culturally more authentic direction: e.g., Is the image of scientific inquiry in schools currently suited to account for the multiple ways in which science generates knowledge? What are scientific inquiry in school's strengths, what are its shortcomings? In how far is a culturally authentic understanding of scientific inquiry in schools necessary or desirable? Whose practices should be the measure stick for scientific inquiry in schools? Who are or were perceived as the most crucial agents in promoting scientific inquiry in schools?

\subsection{The Need to Understand How to Introduce to Scientific Inquiry}

Research can principally account for the non-existence of "the" Scientific Method on a purely descriptive basis: "The concept of the scientific method has little credibility, because there appears to be no evidence of its usage by the world's greatest scientists!" (Brown \& Kumar, 2013, pp. 10-11; see too: Woodcock, 2014). Many more points in argument against "the" Scientific Method might be attributed to the individual researcher and their 


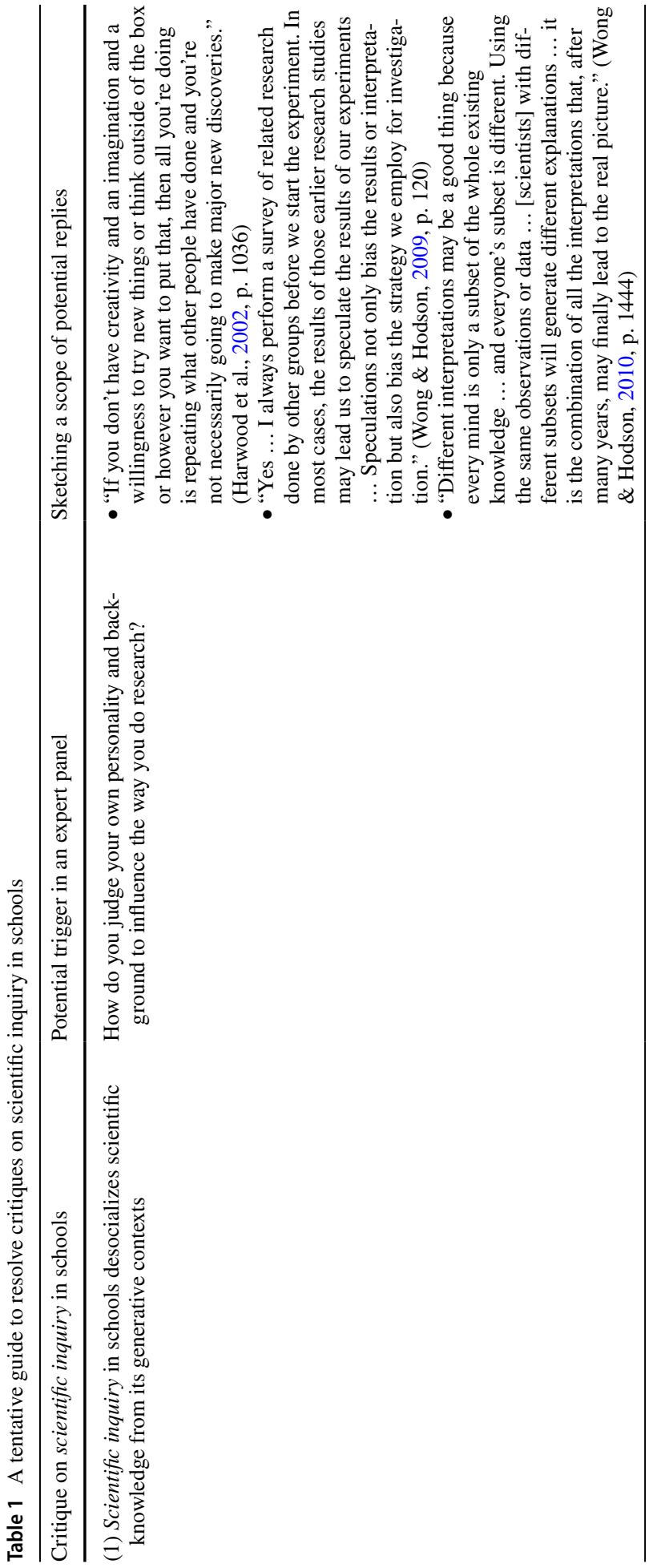




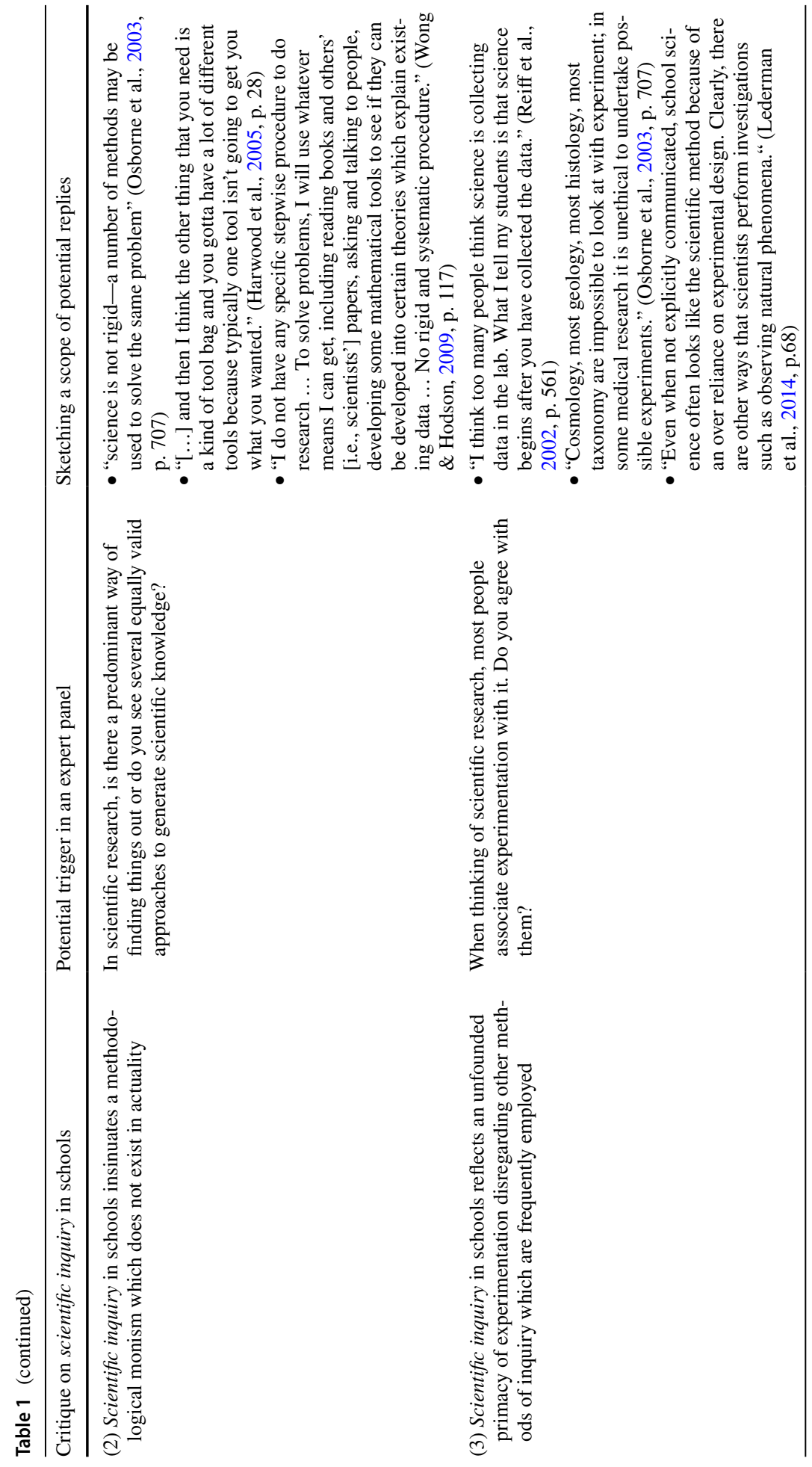




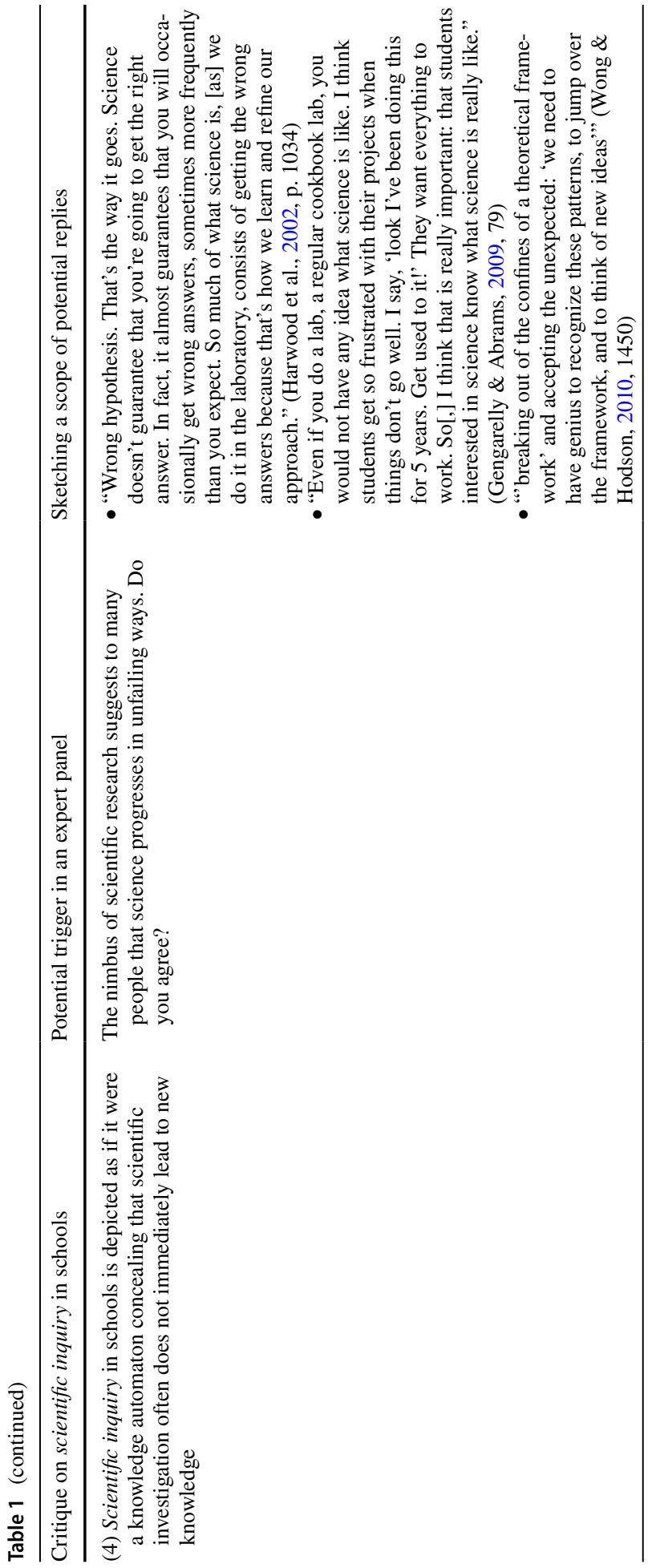




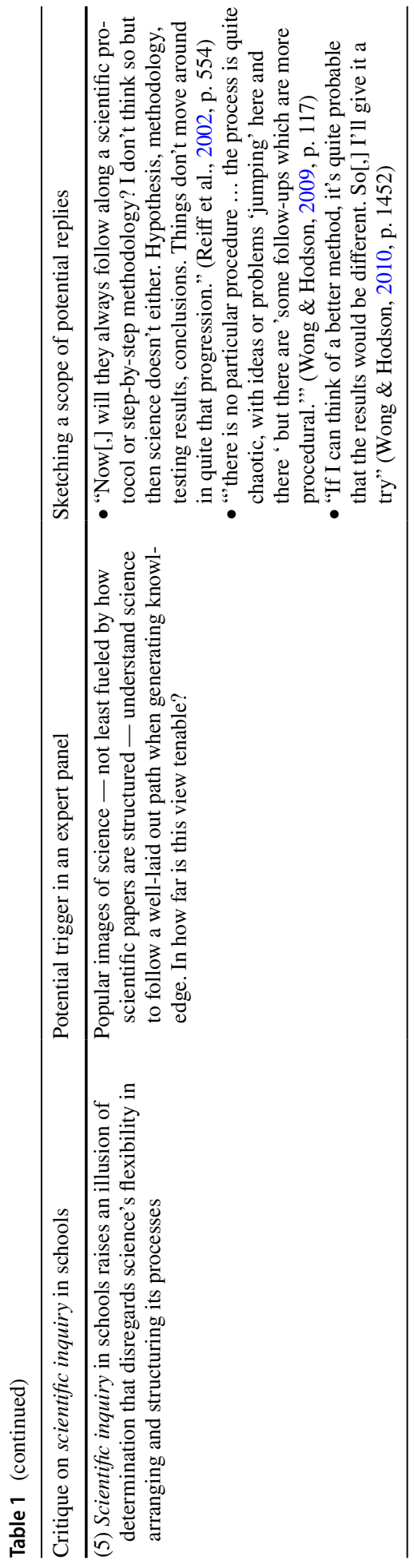


backgrounds (creativity, serendipity, "hunches"). Almost as much might be explained by research scientists' interactions in teams. These teams develop by virtue of their close collaboration; they form epistemic communities (Feldman et al., 2009) that share an epistemic culture (Knorr Cetina, 1999) which in turn guides how their research unfolds. It is within these epistemic communities that junior researchers are introduced to scientific inquiry and into a scientific community by senior researchers.

How can this be accomplished, if there is not some common frame of reference to which the juniors could be introduced and to which the seniors could refer? We certainly must not assume that contemporary laboratory training retains a quasi-medieval character likening it to alchemy, in which adepts were secretively introduced to occult knowledge by masters of the trade. "Adepts" of today are undoubtedly no "pale student[s] of unhallowed arts" (Shelley, 1831, p. x) but methodical, reflective, and well-educated inquirers into nature. Science education needs to understand how these epistemic communities negotiate and pass on their ways of doing research. Otherwise, it may not be fit to find ways of introducing school students to it. Therefore, inquiring with professional research scientists about what they do, how they do it, and how they teach it must precede discussing the results with science education and science philosophy in a second step.

It is to be assumed that a description of the ways of how science generates knowledge, which was developed in close collaboration with research scientists, would find remarkably many parallels to the Practices, scientific inquiry in schools or "the" Scientific Method as none of these ideas has fallen from the blue skies but are results of serious thought on how science generates knowledge. At the same time, it will probably show that our current and recent descriptions are by and large undercomplex (American Association for the Advancement of Science [AAAS], 1993; Reiff et al., 2002; Spiece \& Colosi, 2000) and need to be augmented in order to even approximate cultural authenticity of the sciences.

\section{Introducing to Scientific Inquiry with "the" Scientific Method}

Orienting science education towards cultural authenticity necessarily entails having students successively gain command over a broad knowledge basis. Yet, when introducing young learners to a new field of study, this is unattainable as there is virtually no knowledge basis for them! For beginning learners - principally from the primary level onwards - we need differently tailored, pre-knowledge-lean approaches to learning science, to learning to do science, and to learning about science (e.g., Hodson, 2014). Introducing students to complex processes optimally employs scaffolds (Baur \& Emden, 2021; Kang et al., 2014; Van de Pol et al., 2010) which may be understood as idealized frames of reference which students can resort to when structuring their own processes. For beginning learners, these scaffolds might be rather roughly cut as to keep a low complexity and not to overburden their cognitive capacities (Hmelo-Silver et al., 2007). Throughout the levels of obligatory schooling, concurrent with students' progress in and familiarity with the processes, the scaffolds might be augmented and extended in order to capture the relevant processes more authentically (see Section 8.2).

For a start, however, a clean cut, easily navigable and extendable process structure is sought - why could or should this not be "the" Scientific Method of the article structure? Why could science education not endorse this model as a first steppingstone that needs to be developed into scientific inquiry or professional scientific practices? This is all the more true, as current practice in schools tends to distill "the" Scientific Method from scientific 
inquiry or the Practices anyhow (cf. Alexakos, 2010) — irrespective of how often their authors caution not to do this.

\subsection{Against Practices as a Scaffold for Scientific Inquiry in Schools}

One could object that with the very same arguments the Practices would qualify as a scaffold, maybe even a scaffold that allows to address each practice individually, thereby, decreasing cognitive load (Sweller, 2010). The problem is that most of the Practices are only pseudo-unconnected: it is not the case that science encourages to ask questions without triggering another practice - the same is true of obtaining, evaluating, and communicating information, which is pointless if there has been no question asked before. Examining results necessarily presupposes to have planned and performed an investigation. So, the Practices make some kind of sequence between its components obligatory but veil it by a supposed freedom when doing research. ${ }^{23}$ Introducing the Practices as a scaffold would actually increase the cognitive load for students when conducting an inquiry (Sweller, 2010) - because not only would students have to "juggle" all the available Practices but also they would have to have a grasp of how these connect.

"The" Scientific Method, on the other hand, eases the initial juggling by restricting itself to a definite, low number of elements that are well-aligned and will work for most of the young students' investigations. An introduction through "the" Scientific Method only serves to give students opportunity to familiarize themselves with the process. They would acquire proficiency in the simplified process over time. This careful fading into the process would allow them (and their teachers) to instill degrees of freedom in the investigative processes and to break out of the tight corset. Aiming at variation of a fundamental theme presupposes having mastered the basics - this might be harder to achieve when making the basics already very complex.

\subsection{Extending "the" Scientific Method Throughout the Course of Science Education}

Conceptualizing "the" Scientific Method as a three-stepped process (Question-Investigation-Answer, cf. Figure 1) might be just complex enough for beginning learners at the primary level. When they have mastered to align the three steps in a coherent sequence, a first extension might lie in differentiating the question-step into "Developing a Question - Constructing hypothesis" (Windschitl, 2004, Fig. 1). As hinted above, characterizing an hypothesis could be facilitated by a gradual introduction starting with "descriptive or predictive hypotheses" - at the primary level already — developing them into "causal or explanatory hypotheses" (Wenham, 1993) — possibly not earlier than in the first year of secondary

\footnotetext{
23 While this might remind of Feyerabend's (1975/1993) "Anything goes," there has been a misinterpretation of that dictum at its core for decades. Feyerabend has probably been misunderstood as he was substantially not arguing against method itself but cautioning of an unreflected acceptance of scientific knowledge: "Its [i.e. Against Method] deep message was that the authority of science is conditional and contingent and therefore fragile, and so in need of defense. We must abandon comfortable but false myths-such as methodological monism and the value-free ideal-and take seriously the fact that different publics have different estimates of the value of science. We must not take the authority of science for granted, nor rely upon assumptions or dogmatic assertions of its superiority, which will cut no ice with resisters, sceptics, and deniers. We must bust scientistic myths, ask fundamental questions, acknowledge contingency, and so do our bit, as philosophers of science, to defend the authority of science." (Kidd, 2015, p. 348)
} 
school. When devoting lesson time to this aspect, it would need to be emphasized that the formulation of causal hypothesis sometimes only occurs as an after-thought in science proper (Medawar, 1990; Wong \& Hodson, 2009). Referring to Fig. 1, there surface many more potential developments into finer grained differentiations of "the" three-stepped Scientific Method - taking Pedaste et al., (2015) as a model, a student should not know less than twelve concrete steps or, according to NRC (2011), five sequentiable and three fundamental Practices by the end of secondary schooling. Baur and Emden (2021) suggest more flexible ways of introducing students to a five-stepped structure of scientific inquiry than the rigid linear-fading models of opening scientific inquiry by, e.g., Bell et al. (2005).

At the secondary level, students should explicitly learn to use different methods of inquiry and should be made aware of the generative processes. Modelling should be introduced as such a generative method instead of as a mostly descriptive account. This could be accomplished, e.g., by referring to exercises suggested in Lederman and Abd-El-Khalick (1998) or Lederman et al. (2020): having students speculate about the content of a Manila folder with punch-holes appears to be a good introduction; alternatively, identifying the content of sealed black-boxes has been suggested (e.g., Yayon \& Scherz, 2008) — both exercises are suited for the upper primary, middle school level respectively. It is left to the teacher to decide to open the Manila folder or to x-ray the black-box some decide not to as this option of validating a scientific model is usually not available in reality.

Above this, teaching should convey the idea that experiments do not only test hypotheses (Ioannidou \& Erduran, 2021). Studying the full SDDS-model (Klahr \& Dunbar, 1988), one finds that employing experiments ("Espace move") features in three instances: once to "Test hypothesis" and twice to "Search hypothesis space" (Klahr \& Dunbar, 1988, p. 34). The latter two instantiations assign the experiment the roles of generating a new, specifying an existing hypothesis, respectively - i.e., aspects of exploration come into play and would put the predominance of hypotheticodeductive approaches into perspective. This could serve to illustrate the inherent flexibility of scientific inquiry in which an experiment need not be preceded by a definite hypothesis. This extension of "the" Scientific Method might not be available before the end of lower secondary school.

Lastly — as an outlook into upper secondary education - looking at historic examples (cf. McComas, 2008) might show students that scientific inquiry is more complex and flexible than suggested by "the" Scientific Method. The discovery of Jupiter's moons by Galileo Galilei (Lawson, 2002) contradicts an overreliance on experimentation; Alexander Fleming's discovery of penicillin and its eventual investigation show that scientific inquiry works anything but determinately (Henderson, 1997; Weisse, 1991); the Liebig-Wöhlercontroversy that was finally resolved by the introduction of isomerism (Esteban, 2008) serves nicely to illustrate that there can be more than one correct interpretation to the same observation and, thus, could put the knowledge-automaton-idea into question. These few examples may suffice to show that the history of science could be a viable perspective from which to approach teaching about scientific inquiry (cf. Lederman \& Lederman, 2012). ${ }^{24}$

\section{Conclusion}

In summary, it might be more economic to preserve "the" Scientific Method as an introductory idealization and to put renewed efforts into extending "the" Scientific Method into cumulative, culturally increasingly authentic models of professional scientific practice. The latter ones

\footnotetext{
24 This necessarily entails teaching the Nature of Science (e.g., Akerson \& Hanuscin, 2007) but can only be touched fleetingly in the scope of this manuscript. A valuable source for closer study of this connection can be found in Flick and Lederman (2006) or in McComas (2020a).
} 
need yet to be identified - optimally together with research scientists - and students always need to be made aware of their current working model to be "in flux." After all, most of the currently more refined and supposedly more authentic descriptions of how science generates its knowledge are mute on how they want to be introduced - a laudable exception being the Practices (NRC, 2011). Too often suggestions for teaching scientific inquiry have argued from the end of the schooling process - how science needs to be understood by those who leave school - preferring not to give advice how to get there. This is unwholesome criticism as it does not support important and necessary development: "[...] simply attacking the use of the traditional scientific method would almost certainly fail to provide much assistance to present teachers of science." (Finley \& Pocoví, 2000, p. 48) or: "However, too literal an interpretation of Feyerabend's dictum 'anything goes' is unhelpful. Implying that science has no methods at all constitutes a gross disservice to students" (Hodson, 2009, p. 198).

Science education needs to overcome its habitual biting reflex against "the" Scientific Method and realize its potentials as well as its limitations. Vetoing "the" Scientific Method even from introductory science at the primary level might actually do harm by preferring a primarily science-oriented argument over a student-oriented one: "Science curriculum history is littered with examples of throwing out the baby with the bathwater. Major changes in science curriculum have been due to changes in curriculum orientation from Vision I [i.e. "look[ing] inward at science, to build curriculum"] to Vision II [i.e., "looking outside science to build curriculum"] and vice versa" (Roberts \& Bybee, 2014, p. 556). Should it really be considered progress to deprioritize students' needs (Vision II) against some unattainable depiction of authentic science (Vision I)?

Acknowledgements I should like to thank Dr. Pitt Hild for his valuable comments and suggestions through several draft versions of this manuscript. Moreover, I should like to thank three anonymous reviewers for their open-mindedness towards my claims and for sharing their thoughts on the versions of my manuscript. I have experienced this to be a valuable and very constructive process.

Funding Open Access funding provided by Pädagogische Hochschule Zürich (PH Zürich).

\section{Declaration}

Conflict of Interest The author declares no conflict of interest.

Open Access This article is licensed under a Creative Commons Attribution 4.0 International License, which permits use, sharing, adaptation, distribution and reproduction in any medium or format, as long as you give appropriate credit to the original author(s) and the source, provide a link to the Creative Commons licence, and indicate if changes were made. The images or other third party material in this article are included in the article's Creative Commons licence, unless indicated otherwise in a credit line to the material. If material is not included in the article's Creative Commons licence and your intended use is not permitted by statutory regulation or exceeds the permitted use, you will need to obtain permission directly from the copyright holder. To view a copy of this licence, visit http://creativecommons.org/licenses/by/4.0/.

\section{References}

Abd-El-Khalick, F., BouJaoude, S., Duschl, R. A., Lederman, N. G., Mamlok-Naaman, R., Hofstein, A., \& Tuan, H.-L. (2004). Inquiry in science education: International perspectives. Science Education, $88(3), 397-419$. 
Abrahams, I., \& Millar, R. (2008). Does Practical work really work? A study of the effectiveness of practical work as a teaching and learning method in school science. International Journal of Science Education, 30(14), 1945-1969. https://doi.org/10.1080/09500690701749305 .

Akerson, V. L., \& Hanuscin, D. L. (2007). Teaching nature of science through inquiry: Results of a 3-year professional development program. Journal of Research in Science Teaching, 44(5), 653-680.

Alberts, B. (2000). Some thoughts of a scientist on inquiry. In J. Minstrell \& E. H. van Zee (Eds.), Inquiring into inquiry learning and teaching in science. (pp. 3-13). American Association for the Advancement of Science.

Alexakos, K. (2010). Teaching the practice of science, unteaching the "scientific method." Science Scope, 33(9), 74-79.

Association, A., \& for the Advancement of Science, (Eds.). (1993). Benchmarks for scientific literacy. American Association for the Advancement of Science.

Andersen, H., \& Hepburn, B. (2016). Scientific Method. The Stanford Encyclopedia of Philosophy. Retrieved from https://plato.stanford.edu/archives/sum2016/entries/scientific-method/. Accessed 17.03.2020.

Anker-Hansen, J., \& Andrée, M. (2019). In pursuit of authenticity in science education. NorDiNa, 15(1), 54-66.

Ayala, F. J. (1994). On the scientific method, its practice and pitfalls. History and Philosophy of the Life Sciences, 16(2), 205-240.

Bacon, F. (1752). Novum Organum Scientarium. Editio prima Veneta. Venedig: Gasparis Girardi (Original work published 1620).

Bang, M., \& Medin, D. (2010). Cultural processes in science education: supporting the navigation of multiple epistemologies. Science Education, 94(6), 1008-1026. https://doi.org/10.1002/sce.20392 .

Barrow, L. H. (2006). A brief history of inquiry: from Dewey to standards. Journal of Science Teacher Education, 17(3), 265-278.

Baur, A., \& Emden, M. (2021). How to open inquiry teaching? An alternative teaching scaffold to foster students' inquiry skills. Chemistry Teacher International, 3(1), 1-12. https://doi.org/10.1515/cti-20190013 .

Baur, A., Emden, M., \& Bewersdorff, A. (2019). Welche Unterrichtsprinzipien sollten für den Aufbau von Kompetenzen zum Experimentieren Beachtung finden? Eine Ableitung auf Basis multiperspektivisch begründeter Unterrichtsziele. Zeitschrift Für Didaktik Der Biologie, 23, 10-24. https://doi.org/10. 4119/zdb-1738.

Bell, R. L., Smetana, L., \& Binns, I. (2005). Simplifying inquiry instruction: assessing the inquiry level of classroom activities. The Science Teacher, 72(7), 30-33.

Bevins, S., \& Price, G. (2016). Reconceptualising Inquiry in Science Education. International Journal of Science Education, 38(1), 17-29. https://doi.org/10.1080/09500693.2015.1124300 .

Blachowicz, J. (2009). How science textbooks treat scientific method: a philospoher's perspective. The British Journal for the Philosophy of Science, 60(2), 303-344.

Black Elk, L. (2016). Native science: understanding and respecting other ways of thinking. Rangelands, 38(1), 3-4. https://doi.org/10.1016/j.rala.2015.11.003 .

Bond-Robinson, J., \& Stucky, A. P. (2005). Grounding scientific inquiry and knowledge in situated cognition. Proceedings of the Annual Meeting of the Cognitive Science, 27, 310-316.

Brown, R. A., \& Kumar, A. (2013). The scientific method: Reality or myth. Journal of College Science Teaching, 42(4), 10-11.

Bruner, J. (1973). The Act of Discovery. In J. Bruner (Ed.), On knowing: essays for the left hand. (pp. 81-96). Atheneum.

Burgin, S. R. (2020). A three-dimensional conceptualization of authentic inquiry-based practices: A reflective tool for science educators. International Journal of Science Education, 42(9), 1465-1485. https:// doi.org/10.1080/09500693.2020.1766152 .

Bybee, R. W. (2011). Scientific and engineering practices in K-12 classrooms: Understanding a framework for K-12 science education. Science and Children, 49(4), 10-16.

Cantor, G. (1989). The Rhetoric of Experiment. In D. Gooding, T. Pinch, \& S. Schaffer (Eds.), The uses of experiment. (pp. 159-180). Cambridge University Press.

Cajete, G. A. (2004). Philosophy of Native Science. In A. Waters (Ed.), American Indian thought: Philosophical essays (pp. 45-57). Blackwell Publ.

Cajete, G. A. (2005). American Indian epistemologies. New Directions for Student Services, 2005(109), 69-78. https://doi.org/10.1002/ss.155 .

Chang Rundgren, S.-N., \& Rundgren, C.-J. (2017). What are we aiming for? A Delphi study on the development of civic scientific literacy in Sweden. Scandinavian Journal of Educational Research, 61(2), 224-239. https://doi.org/10.1080/00313831.2015.1120231 . 
Chinn, C. A., \& Malhotra, B. A. (2002). Epistemologically authentic inquiry in schools: A theoretical framework for evaluating inquiry tasks. Science Education, 86(2), 175-218. https://doi.org/10.1002/ sce. 10001 .

Clough, M. P. (2000). The nature of science: Understanding how the game of science is played. The Clearing House, 74(1), 13-17. https://doi.org/10.1080/00098655.2000.11478631 .

Crawford, B. A. (2014). From inquiry to scientific practices in the science classroom. In N. G. Lederman \& S. K. Abell (Eds.), Handbook of research on science education. (Vol. II, pp. 515-541). Routledge.

Crowell, V. L. (1937). The scientific method. School Science and Mathematics, 37(5), 525-531. https://doi. org/10.1111/j.1949-8594.1937.tb11286.x .

DeBoer, G. E. (2006). Historical perspectives on inquiry teaching in schools. In L. B. Flick \& N. G. Lederman (Eds.), Scientific inquiry and nature of science. (pp. 17-35). Kluwer Academic Publishers.

Demtröder, W. (2015). Experimentalphysik 1: Mechanik und Wärme (7th edition). Springer Spektrum. https://doi.org/10.1007/978-3-662-46415-1 .

Dewey, J. (1910a). How we think. Heath \& Company.

Dewey, J. (1910b). Science as subject-matter and as method. Science, 31(787), 121-127.

Dewey, J. (1938). Logic - the theory of inquiry. Henry Holt.

Donnelly, J. (2005). Reforming science in the school curriculum: A critical analysis. Oxford Review of Education, 31(2), 293-309. https://doi.org/10.1080/03054980500117934 .

Dunbar, K. (2000). How scientists think in the real world: Implications for science education. Journal of Applied Developmental Psychology, 21(1), 49-58.

Duschl, R. (2008). Science education in three-part harmony: Balancing conceptual, epistemic, and social learning goals. Review of Research in Education, 32(1), 268-291. https://doi.org/10.3102/00917 32X07309371.

Emden, M. (2011). Prozessorientierte Leistungsmessung des naturwissenschaftlich-experimentellen Arbeitens. Logos.

Emden, M., \& Baur, A. (2017). Effektive Lehrkräftebildung zum Experimentieren: Entwurf eines integrierten Wirkungs- und Gestaltungsmodells. Zeitschrift Für Didaktik Der Naturwissenschaften, 23(1), 1-19. https://doi.org/10.1007/s40573-016-0052-1 .

Emden, M., \& Gerwig, M. (2020). Can the chemical history of a candle inform the teaching of experimentation? An hermeneutic approach regarding the potentials for teaching scientific inquiry from a proven historic exemplar. Science \& Education, 29(3), 589-616. https://doi.org/10.1007/s11191020-00119-5 .

Emden, M., \& Sumfleth, E. (2016). Assessing students' experimentation processes in guided inquiry. International Journal of Science and Mathematics Education, 14(1), 29-54. https://doi.org/10. 1007/s10763-014-9564-7.

Erduran, S., \& Dagher, Z. R. (2014). Reconceptualizing the nature of science for science education. Springer, Netherlands.

Esteban, S. (2008). Liebig-Wöhler controversy and the concept of Isomerism. Journal of Chemical Education, 85(9), 1201-1203.

Faraday, M. (1827). Chemical manipulation. W. Phillips.

Feldman, A., Divoll, K., \& Rogan-Klyve, A. (2009). Research education of new scientists: Implications for science teacher education. Journal of Research in Science Teaching, 46(4), 442-459. https:// doi.org/10.1002/tea.20285 .

Feyerabend, P. K. (1993). Against method (3rd ed.). Verso. (Original work published: 1975).

Finley, F. N., \& Pocoví, M. C. (2000). Considering the scientific method of inquiry. In J. Minstrell \& E. $\mathrm{H}$. van Zee (Eds.), Inquiring into inquiry learning and teaching in science. (pp. 47-62). American Association for the Advancement of Science.

Flick, L. B., \& Lederman, N. G. (Eds.). (2006). Scientific inquiry and nature of science: implications for teaching, learning, and teacher education. Kluwer Academic Publishers.

Ford, M. J. (2015). Educational implications of choosing "practice" to describe science in the next generation science standards. Science Education, 99(6), 1041-1048. https://doi.org/10.1002/sce. 21188 .

Franklin, A. (1989). The epistemology of experiment. In D. Gooding, T. Pinch, \& S. Schaffer (Eds.), The uses of experiment. (pp. 437-460). Cambridge University Press.

French, D. P. (2006). Don't confuse inquiry and discovery. Journal of College Science Teaching, 35(6), 58-59.

Furtak, E. M., \& Penuel, W. R. (2019). Coming to terms: Addressing the persistence of "hands-on" and other reform terminology in the era of science as practice. Science Education, 103(1), 167-186. https://doi.org/10.1002/sce.21488 . 
Furtak, E. M., Seidel, T., Iverson, H., \& Briggs, D. C. (2012a). Experimental and quasi-experimental studies of inquiry-based science teaching: A meta-analysis. Review of Educational Research, 82(3), 300-329. https://doi.org/10.3102/0034654312457206.

Furtak, E. M., Shavelson, R. J., Shemwell, J. T., \& Figueroa, M. (2012b). To teach or not to teach through inquiry. In S. M. Carver, \& J. Shrager (Eds.), Decade of behavior. The journey from child to scientist: Integrating cognitive development and the education sciences (pp. 227-244). American Psychological Association.

Gagné, R. M. (1965). The psychological bases of science - a process approach (AAAS Miscellaneous Publication No. 65-8). Washington, D.C.

García-Carmona, A. (2020). From inquiry-based science education to the approach based on scientific practices: A critical analysis and suggestions for science teaching. Science \& Education, 88(3), 397-417. https://doi.org/10.1007/s11191-020-00108-8 .

Gaskell, P. J. (1992). Authentic science and school science. International Journal of Science Education, 14(3), 265-272. https://doi.org/10.1080/0950069920140303.

Gengarelly, L. M., \& Abrams, E. D. (2009). Closing the gap: Inquiry in research and the secondary science classroom. Journal of Science Education and Technology, 18(1), 74-84.

Gilbert, J. K. (2004). Models and modelling: Routes to more authentic science education. International Journal of Science and Mathematics Education, 2(2), 115-130.

Gillies, D. (2006). Kuhn on discovery and the case of penicillin. In W. J. González \& J. Alcolea Banegas (Eds.), Contemporary perspectives in philosophy and methodology of science (pp. 47-63). Netbiblo.

Gogolin, S., \& Krüger, D. (2018). Students' understanding of the nature and purpose of models. Journal of Research in Science Teaching, 33(9), 1313-1338. https://doi.org/10.1002/tea.21453 .

Gooding, D. (1985). 'in Nature's School': Faraday as an experimentalist. In D. Gooding \& F. A. J. L. James (Eds.), Faraday rediscovered: Essays on the life and work of Michael Faraday, 1791-1867. (pp. 105135). Macmillan.

Gooding, D. (1991). Faraday was a hands-on-scientist. Physics Education, 26(5), 307-312.

Gower, B. (1997). Scientific method: An historical and philosophical introduction. Routledge.

Grinnell, F. (2013). Research integrity and everyday practice of science. Science and Engineering Ethics, 19(3), 685-701. https://doi.org/10.1007/s11948-012-9376-5 .

Haack, S. (1995). Puzzling out Science. Academic Questions, 8(2), 20-34.

Hammann, M., Phan, T. T. H., Ehmer, M., \& Grimm, T. (2008). Assessing pupils' skills in experimentation. Journal of Biological Education, 42(2), 66-72.

Haraway, D. (1988). Situated knowledges: The science question in feminism and the privilege of partial perspective. Feminist Studies, 14(3), 575-599.

Harding, S. (1987). The method question. Hypatia, 2(3), 19-35.

Harding, S. (1992). Rethinking standpoint epistemology: What is "strong objectivity?" The Centennial Review, 36(3), 437-470.

Harwood, W. S. (2004). An activity model for scientific inquiry. The Science Teacher, 76(1), 44-46.

Harwood, W. S. (2004). A new model for inquiry: Is the scientific method dead? Journal of College Science Teaching, 33(7), 29-33.

Harwood, W. S., Reiff, R., \& Phillipson, T. (2002). Scientists' conceptions of scientific inquiry: Voices from the front. In P. A. Rubba, J. A. Rye, W. J. DiBiase, \& B. A. Crawford (Eds.), Proceedings. (pp. 10221052). Association for the Education of Teachers. in Science.

Harwood, W. S., Reiff, R., \& Phillipson, T. (2005). Putting the puzzle together: Scientists' metaphors for scientific inquiry. Science Educator, 14(1), 25-30.

Hellstrom, P.-M. (2006). This year's Nobel Prize to gastroenterology: Robin Warren and Barry Marshall awarded for their discovery of Helicobacter pylori as pathogen in the gastrointestinal tract. World Journal of Gastroenterology, 12(19), 3126-3127. https://doi.org/10.3748/wjg.v12.i19.3126 .

Henderson, J. W. (1997). The yellow brick road to penicillin: A story of serendipity. Mayo Clinic Proceedings, 72(7), 683-687.

Herron, M. D. (1971). The nature of scientific enquiry. The School Review, 79(2), 171-212.

Hintikka, J. (2005). Omitting data-Ethical or strategic problem? Synthese, 145(2), 169-176. https://doi. org/10.1007/s11229-005-3745-4 .

Hmelo-Silver, C. E., Duncan, R. G., \& Chinn, C. A. (2007). Scaffolding and achievement in problem-based and inquiry learning: A response to Kirschner, Sweller, and Clark (2006). Educational Psychologist, 42(2), 99-107.

Hodson, D. (1988). Experiments in science and science teaching. Educational Philosophy and Theory, 20(2), 53-66.

Hodson, D. (1996). Laboratory work as scientific method: Three decades of confusion and distortion. Journal of Curriculum Studies, 28(2), 115-135. 
Hodson, D. (1998). Science fiction: The continuing misrepresentation of science in the school curriculum. Curriculum Studies, 6(2), 191-216. https://doi.org/10.1080/14681369800200033 .

Hodson, D. (2009). Teaching and learning about science: Language, theories, methods, history, traditions and values. Sense Publishers.

Hodson, D. (2014). Learning science, learning about science, doing science: Different goals demand different learning methods. International Journal of Science Education, 36(15), 2534-2553. https://doi. org/10.1080/09500693.2014.899722.

Hofstein, A., \& Kind, P. M. (2012). Learning in and from science laboratories. In B. J. Fraser, K. G. Tobin, \& C. J. McRobbie (Eds.), Second International Handbook of Science Education. (pp. 189-207). Springer.

Hofstein, A., \& Lunetta, V. N. (2004). The laboratory in science education: Foundations for the twenty-first century. Science Education, 88(1), 28-54.

Howitt, S. M., \& Wilson, A. N. (2014). Revisiting "Is the scientific paper a fraud?" EMBO Reports, 15(5), 481-484. https://doi.org/10.1002/embr.201338302 .

Hume, A. (2009). Authentic Inquiry and School Science. Teaching Science, 55(2), 35-41.

Ioannidou, O., \& Erduran, S. (2021). Beyond hypothesis testing. Science \& Education, 30(2), 345-364. https://doi.org/10.1007/s11191-020-00185-9.

Jackson, P. A., Jr. (1969). Some philosophical and educational thoughts on the nature of scientific inquiry. The Savannah State College Bulletin, 23(2), 27-37.

James, F. A. J. L. (Ed.). (2007). Christmas at the Royal Institution. An anthology of lectures. World Scientific.

Jenkins, E. (2007). School science: A questionable construct? Journal of Curriculum Studies, 39(3), 265282. https://doi.org/10.1080/00220270701245295.

Justi, R. S., \& Gilbert, J. K. (2000). History and philosophy of science through models: Some challenges in the case of 'The Atom.' International Journal of Science Education, 22(9), 993-1009. https://doi.org/ $10.1080 / 095006900416875$.

Justi, R., \& van Driel, J. H. (2005). The development of science teachers' knowledge on models and modelling: promoting, characterizing, and understanding the process. International Journal of Science Education, 27(5), 549-573. https://doi.org/10.1080/0950069042000323773 .

Kang, H., Thompson, J., \& Windschitl, M. (2014). Creating opportunities for students to show what they know: The role of scaffolding in assessment tasks. Science Education, 98(4), 674-704. https://doi.org/ $10.1002 /$ sce. 21123 .

Kant, I. (1883). Kant's Prolegomena and Metaphysical Foundations of Natural Science. translated by Ernest Belfort Max. George Bell and Sons. (Original work published: 1783).

Kant, I. (1998). The critique of pure reason. Translated and edited by Paul Guyer and Allen W. Wood. The Cambridge edition of the works of Immanuel Kant. Cambridge University Press (Original work published 1781).

Kapon, S., Laherto, A., \& Levrini, O. (2018). Disciplinary authenticity and personal relevance in school science. Science Education, 102(5), 1077-1106. https://doi.org/10.1002/sce.21458 .

Kaufmann, F. (1959). John Dewey's theory of inquiry. The Journal of Philosophy, Psychology and Scientific Methods, 56(21), 826-836.

Keeslar, O. (1945). The elements of scientific method. Science Education, 29(5), 273-278.

Kempa, R. (1986). Assessment in science. Cambridge University Press.

Kidd, I. J. (2015). What's so great about Feyerabend? Against Method, forty years on. Metascience, 24(3), 343-349. https://doi.org/10.1007/s11016-015-0004-2 .

Kipnis, M., \& Hofstein, A. (2008). The inquiry laboratory as a source for development of metacognitive skills. International Journal of Science and Mathematics Education, 6(3), 601-627.

Kirschner, P. A. (1992). Epistemology, practical work and academic skills in science education. Science \& Education, 1(3), 273-299.

Kirschner, P. A. (2009). Epistemology or pedagogy, that is the Question. In S. Tobias \& T. M. Duffy (Eds.), Constructivist instruction: Success or failure? (pp. 144-157). Routledge.

Kirschner, P. A., Sweller, J., \& Clark, R. E. (2006). Why minimal guidance during instruction does not work: An analysis of the failure of constructivist, discovery, problem-based, experiential, and inquirybased teaching. Educational Psychologist, 41(2), 75-86.

Klahr, D., \& Dunbar, K. (1988). Dual space search during scientific reasoning. Cognitive Science, 12(1), $1-48$.

Kloser, M. (2014). Identifying a core set of science teaching practices: A Delphi expert panel approach. Journal of Research in Science Teaching, 51(9), 1185-1217. https://doi.org/10.1002/tea.21171 .

Knorr Cetina, K. (1999). Epistemic cultures: How the sciences make knowledge. Harvard University Press.

Kosso, P. (2009). The large-scale structure of scientific method. Science \& Education, 18(1), 33-42. 
Kuhn, T. S. (1962a). Historical structure of scientific discovery. Science, 136(3518), 760-764.

Kuhn, T. S. (1962b). The structure of scientific revolutions. University of Chicago Press.

Lakatos, I. (1999). The methodology of scientific research programmes: Cambridge University Press. (Original work published 1978).

Lampkin, R. H. (1951). Scientific inquiry for science teachers. Science Education, 35(1), 17-39.

Lawson, A. E. (2002). What does Galileo's discovery of Jupiter's moons tell us about the process of scientific discovery? Science \& Education, 11(1), 1-24.

Lazonder, A. W. (2014). Inquiry learning. In J. M. Spector (Eds.), Handbook of research on educational communications and technology (4th ed., pp. 453-464). Springer. https://doi.org/10.1007/978-14614-3185-5_36.

Lederman, N. G., \& Abd-El-Khalick, F. (1998). Avoiding de-natured science. Activities that promote understandings of the nature of science. In W. F. McComas (Ed.), The Nature of Science in Science Education: Rationales and Strategies (pp. 83-126). Kluwer Academic Publishers.

Lederman, N. G., \& Lederman, J. S. (2012). Nature of scientific knowledge and scientific inquiry: Building instructional capacity through professional development. In B. J. Fraser, K. G. Tobin, \& C. J. McRobbie (Eds.), Second International Handbook of Science Education. (pp. 335-359). Springer.

Lederman, J. S., Lederman, N. G., Bartos, S. A., Bartels, S. L., Meyer, A. A., \& Schwartz, R. S. (2014). Meaningful assessment of learners' understandings about scientific inquiry: The views about scientific inquiry (VASI) questionnaire. Journal of Research in Science Teaching, 51(1), 65-83. https://doi.org/10.1002/tea.21125 .

Lederman, N. G. (2007). Nature of science: Past, present, and future. In S. K. Abell \& N. G. Lederman (Eds.), Handbook of Research on Science Education. (pp. 831-879). Erlbaum.

Lederman, N. G., Abd-El-Khalick, F., \& Lederman, J. S. (2020). Avoiding de-natured science: Integrating nature of science into science instruction. In W. F. McComas (Ed.), Nature of Science in Science Instruction (pp. 295-326). Springer International Publishing.

Leonardo da Vinci (1478-1519). Codex Atlanticus: Disegni di Machine et delle Arti Secreti et Altre Cose di Leonardo da Vinci. Racolta da Pompeo Leo. Retrieved from https://www.leonardodigitale. com/en/browse/codex-atlanticus/0001-r/. Accessed 26 Apr 2022.

Liebig, J. v (1863). Ueber Francis Bacon von Verulam und die Methode der Naturforschung. Literarisch-artistische Anstalt der J. G. Cotta'schen Buchhandlung.

Liebig, J. v. (1865). Induction und Deduction. Rede gehalten in der in der k. Akademie der Wissenschaften am 28. März 1865. Verlag der königlichen Akademie.

Linder, A., \& Svedberg, W. (2019). Review of average sized male and female occupant models in European regulatory safety assessment tests and European laws. Accident Analysis and Prevention, 127, 156-162. https://doi.org/10.1016/j.aap.2019.02.030 .

Litt, T. (1959). Naturwissenschaft und Menschenbildung. Heidelberg: Quelle und Meyer.

Lunetta, V. N. (1998). The school science laboratory: Historical perspectives and contexts for contemporary teaching. In B. J. Fraser \& K. G. Tobin (Eds.), International Handbook of Science Education. (pp. 249-262). Kluwer Academic Publishers.

Mach, E. (1917). Erkenntnis und Irrtum. (3rd ed.). Johann Ambrosius Barth.

Manz, E., Lehrer, R., \& Schauble, L. (2020). Rethinking the classroom science investigation. Journal of Research in Science Teaching, 57(7), 1148-1174. https://doi.org/10.1002/tea.21625 .

Marshall, B. J., Armstrong, J. A., McGechie, D. B., \& Glancy, R. J. (1985). Attempt to fulfil Koch's postulates for pyloric campylobacter. The Medical Journal of Australia, 142(8), 436-439.

Marshall, B. J., \& Warren, J. R. (1984). Unidentified curved Bacilli in the stomach of patients with gastritis and peptic ulceration. The Lancet, 323(8390), 1311-1315. https://doi.org/10.1016/S01406736(84)91816-6 .

Martin, B., Kass, H., \& Brouwer, W. (1990). Authentic science: A diversity of meanings. Science Education, 74(5), 541-554.

Maslow, A. H. (1966). The psychology of science: A Reconaissance. Harper \& Row.

Mayer, R. E. (2004). Should there be a three-strikes rule against pure discovery learning?: The case for guided methods of instruction. American Psychologist, 59(1), 14-19.

McComas, W. F. (1996). Ten myths of science: Reexamining: What we think we know about the nature of science. School Science and Mathematics, 96(1), 10-16. https://doi.org/10.1111/j.1949-8594. 1996.tb10205.x .

McComas, W. F. (2005). Laboratory Instruction in the service of science teaching and learning: Reinventing and revigorating the laboratory experience. The Science Teacher, 72(7), 24-29.

McComas, W. F. (2008). Seeking historical examples to illustrate key aspects of the nature of science. Science \& Education, 17(2-3), 249-263. 
McComas, W. F., \& Nouri, N. (2016). The nature of science and the next generation science standards: Analysis and critique. Journal of Science Teacher Education, 27(5), 555-576. https://doi.org/10. 1007/s10972-016-9474-3.

McComas, W. F. (Ed.). (2020a). Nature of science in science instruction. Springer International Publishing.

McComas, W. F. (2020b). Principal elements of nature of science: Infomring science teaching while dispelling the myths. In W. F. McComas (Ed.), Nature of science in science instruction (pp. 35-65). Springer International Publishing.

McCurdy, E. (Ed.). (1923). Leonardo da Vinci's Note-Books. Empire State Book Company.

Medawar, P. B. (1990). Is the scientific paper a fraud? In D. Pyke (Ed.), The threat and the glory: Reflections on science and scientists. (pp. 228-233). Oxford University Press.

Meuler, D. A. (2012). The bacterial theory of ulcers: A Nobel-Prize-winning discovery. In C. F. Herreid, N. A. Schiller, \& K. F. Herreid (Eds.), Science stories: Using case studies to teach critical thinking. (pp. 69-79). National Science Teachers Association.

Michaels, S., Shouse, A. W., \& Schweingruber, H. A. (2008). Ready, Set, SCIENCE! Putting research to work in K-8 science classrooms. National Academies Press. https://doi.org/10.17226/11882 .

Miller, E., Manz, E., Russ, R., Stroupe, D., \& Berland, L. (2018). Addressing the epistemic elephant in the room: Epistemic agency and the next generation science standards. Journal of Research in Science Teaching, 55(7), 1053-1075. https://doi.org/10.1002/tea.21459 .

Murphy, P., Lunn, S., \& Jones, H. (2006). The impact of authentic learning on students' engagement with physics. The Curriculum Journal, 17(3), 229-246. https://doi.org/10.1080/09585170600909688 .

National Research Council, N. R., \& [NRC], (Eds.). (1996). National Science Education Standards. National Academy Press.

Nobel Foundation (1923).The Nobel Prize in Physics 1923. Retrieved from https://www.nobelprize.org/ prizes/physics/1923/summary/.

Nobel Foundation (1945). The Nobel Prize in Physiology or Medicine 1945. Retrieved from https://www. nobelprize.org/prizes/medicine/1945/summary/.

Nobel Foundation (1960). The Nobel Prize in Physiology or Medicine 1960. Retrieved from https://www. nobelprize.org/prizes/medicine/1960/summary/.

Nobel Foundation (1962). The Nobel Prize in Physiology or Medicine 1962. Retrieved from https://www. nobelprize.org/prizes/medicine/1962/summary/.

Nobel Foundation (2005). The Nobel Prize in Physiology or Medicine 2005. Retrieved from https://www. nobelprize.org/prizes/medicine/2005/summary/.

NRC. (2011). A Framework for K-12 Science Education: Practices, Crosscutting Concepts, and Core Ideas. National Academy Press.

NGSS Lead States (Ed.) (2013). Next generation science standards: By states, for states. National Academy Press.

Olesko, K. M. (2015). Myth 25 - That science has been largely a solitary enterprise. In K. Kampourakis \& R. L. Numbers (Eds.), Newton's apple and other myths about science. (pp. 202-209). Harvard University Press.

Organisation for Economic Co-Operation and Development [OECD] (Ed.) (2000). Measuring student knowledge and skills: The PISA 2000 assessment of reading, mathematical and scientific literacy. OECD.

OECD (2003). The PISA 2003 Assessment Framework: Mathematics, reading, science and problem solving knowledge and skills. paris: oecd.

OECD. (2006). Assessing scientific, reading and mathematical literacy: A framework for PISA 2006. OECD.

OECD. (2009). PISA 2009 Assessment Framework: Key competencies in reading, mathematics and science. OECD.

OECD. (2013). PISA. Pisa 2012 assessment and analytical framework. OECD.

OECD. (2016). PISA 2015 Assessment and Analytical Framework. OECD. https://doi.org/10.1787/97892 64255425-en .

OECD. (2019). PISA 2018 Assessment and Analytical Framework. OECD. https://doi.org/10.1787/b25ef ab8-en .

Osborne, J. (2011). Science teaching methods: a rationale for practices. School Science Review, 93(343), 93-103.

Osborne, J. (2014). Teaching scientific practices: Meeting the challenge of change. Journal of Science Teacher Education, 25(2), 177-196. https://doi.org/10.1007/s10972-014-9384-1 .

Osborne, J. (2015). Practical work in science: Misunderstood and badly used? School Science Review, 96(357), 16-24. 
Osborne, J. (2019). Not "hands on" but "minds on": A response to Furtak and Penuel. Science Education, 103(5), 1280-1283. https://doi.org/10.1002/sce.21543 .

Osborne, J., Collins, S., Ratcliffe, M., Millar, R., \& Duschl, R. A. (2003). What "ideas-about-science" should be taught in school science? - A Delphi study of the expert community. Journal of Research in Science Teaching, 40(7), 692-720.

Pedaste, M., Mäeots, M., Siiman, L. A., de Jong, T., van Riesen, S. A. N., Kamp, E. T., \& Tsourlidaki, E. (2015). Phases of inquiry-based learning: Definitions and the inquiry cycle. Educational Research Review, 14, 47-61. https://doi.org/10.1016/j.edurev.2015.02.003 .

Peirce, C. S. (1974). Lecture VII. Pragmatism and Abduction. In C. Hartshorne \& P. Weiss (Eds.), Collected Papers of Charles Sanders Peirce: Volume V. Pragmatism an Pragmaticism (4th ed., pp. 112-131). Belknap Press of Harvard University Press. (Original work published 1903).

Pincock, S. (2005). Nobel Prize winners Robin Warren and Barry Marshall. The Lancet, 366(9495), 1429. https://doi.org/10.1016/S0140-6736(05)67587-3 .

Platt, W., \& Baker, R. (1931). The Relation of the Scientific "Hunch" to Research. Journal of Chemical Education, 8(10), 1969-2002.

Popper, K. R. (1985). Knowledge without authority. In D. W. Miller (Ed.), Popper selections (pp. 46-57). Princeton Univ. Press (Original work published 1960).

Popper, K. R. (2008). The Logic of scientific discovery. Routledge (Original work published 1959).

Radder, H. (2009). The philosophy of scientific experimentation: A review. Automated Experimentation, 1(1). https://doi.org/10.1186/1759-4499-1-2 .

Reiff, R., Harwood, W. S., \& Phillipson, T. (2002). A scientific method based upon research scientists' conceptions of scientific inquiry. In P. A. Rubba, J. A. Rye, W. J. DiBiase, \& B. A. Crawford (Eds.), Proceedings. (pp. 546-569). Association for the Education of Teachers in Science.

Roberts, D. A., \& Bybee, R. W. (2014). Scientific literacy, science literacy, and science education. In N. G. Lederman \& S. K. Abell (Eds.), Handbook of research on science education. (pp. 545-558). Routledge.

Robinson, W. R. (2004). The inquiry wheel, an alternative to the scientific method: A view of the science education research literature. Journal of Chemical Education, 81(6), 791. https://doi.org/10. 1021/ed081p791 .

Rudolph, J. L. (2005). Epistemology for the masses: The origins of "the scientific method" in American schools. History of Education Quarterly, 45(3), 342-376.

Russ, R. S. (2014). Epistemology of science vs. epistemology for science. Science Education, 98(3), 388-396. https://doi.org/https://doi.org/10.1002/sce.21106.

Saunders-Stewart, K. S., Gyles, P. D. T., \& Shore, B. M. (2012). Student outcomes in inquiry instruction: A literature-derived inventory. Journal of Advanced Academics, 23(1), 5-31. https://doi.org/ $10.1177 / 1932202 X 11429860$.

Schwab, J. J. (1960a). Inquiry, the science teacher, and the educator. The School Review, 68(2), 176-195. https://doi.org/10.1086/442536.

Schwab, J. J. (1960b). What do scientists do? Behavioral Science, 5(1), 1-27.

Schwab, J. J. (1966). The teaching of science as enquiry. In President and Fellows of Harvard College (Ed.), The Teaching of Science (pp. 3-103). Harvard University Press.

Selby, C. C. (2006a). The missing person in science: Inquiry starts with "I". Update. The New York Academy of Sciences Magazine. (May/June), 10-13.

Selby, C. C. (2006b). What makes it science? A modern look at scientific inquiry. Journal of College Science Teaching, 35(7), 8-11.

Shaw, P. (1733). The philosophical works of Francis Bacon, Baron of Verulam, Viscount St. Albans and Lord High Chancellor of England. In Three Volumes (vol. II). J. J. Knapton [u. a.]. Retrieved from https://archive.org/details/philosophicalwor02baco/page/n5/mode/2up. Accessed 2 July 2020.

Shelley, M. W. (1831). Frankenstein. Colburn and Bentley.

Sjöström, J. (2013). Towards Bildung-oriented chemistry education. Science \& Education, 22(7), 18731890. https://doi.org/10.1007/s11191-011-9401-0 .

Sjöström, J., \& Eilks, I. (2020). The Bildung theory-From von Humboldt to Klafki and beyond. In Akpan \& Acuna (Eds.), Science Education in Theory and Practice (pp. 55-67). Springer International Publishing. https://doi.org/10.1007/978-3-030-43620-9_5.

Spiece, K. R., \& Colosi, J. (2000). Redefining the "scientific method." The American Biology Teacher, $62(1), 32-40$.

Strasser, B. (2012). Collecting nature: Practices, styles, and narratives. Osiris, 27(1), 303-340.

Sweller, J. (2010). Element interactivity and intrinsic, extraneous, and germane cognitive load. Educational Psychology Review, 22(2), 123-138. 
Sweller, J., Kirschner, P. A., \& Clark, R. E. (2007). Why minimally guided teaching techniques do not work: A reply to commentaries. Educational Psychologist, 42(2), 115-121.

Tang, X., Coffey, J. E., Elby, A., \& Levin, D. M. (2009). The scientific method and scientific inquiry: Tensions in teaching and learning. Science Education, 69(3), 29-47. https://doi.org/10.1002/sce. 20366 .

Tibbetts, P. (1977). Feyerabend's 'Against Method': The case for methodological pluralism. Philosophy of the Social Sciences, 7(3), 265-275.

Truran, P. (2013). Testing hypotheses. In P. Truran (Ed.), Practical applications of the philosophy of science (pp. 47-53). Springer International Publishing. https://doi.org/10.1007/978-3-319-00452-5_ 8.

Tweney, R. D. (2006). Discovering discovery: How Faraday found the first metallic colloid. Perspectives on Science, 14(1), 97-121.

Van de Pol, J., Volman, M., \& Beishuizen, J. (2010). Scaffolding in teacher-student interaction: A decade of research. Educational Psychology Review, 22(3), 271-296. https://doi.org/10.1007/s10648-010-9127-6.

Wee, B., Shepardson, D., Fast, J., \& Harbor, J. (2007). Teaching and learning about inquiry: Insights and challenges in professional development. Journal of Science Teacher Education, 18(1), 63-89.

Weisse, A. B. (1991). The long pause: The discovery and rediscovery of penicillin. Hospital Practice, 26(8), 93-118. https://doi.org/10.1080/21548331.1991.11705281.

Weizsäcker, C. F. (1952). The world view of physics. University of Chicago Press.

Wenham, M. (1993). The nature and role of hypotheses in school science investigations. International Journal of Science Education, 15(3), 231-240.

Wieman, C. E. (2015). Comparative cognitive task analyses of experimental science and instructional laboratory courses. The Physics Teacher, 53(6), 349-351. https://doi.org/10.1119/1.4928349 .

Wilcox, J., Kruse, J. W., \& Clough, M. P. (2015). Science through inquiry: Seven common myths about this time-honored approach. The Science Teacher, 82(6), 62-67.

Williams, J. (2008). The scientific method and school science. Journal of College Science Teaching, 38(1), 14-16.

Williams, L. P. (1968). Epistemology and experiment: The case of Michael Faraday. In I. Lakatos \& A. Musgrave (Eds.), Problems in the Philosophy of Science. (pp. 231-248). North Holland Publishing.

Wilson, J. T. (1974). Processes of scientific inquiry: A model for teaching and learning science. Science Education, 58(1), 127-133.

Windschitl, M. (2004). Folk theories of "inquiry": How preservice teachers reproduce the discourse and practices of an atheoretical scientific method. Journal of Research in Science Teaching, 41(5), 481512. https://doi.org/10.1002/tea.20010 .

Windschitl, M., Thompson, J., \& Braaten, M. (2008). Beyond the scientific method: Model-based inquiry as a new paradigm of preference for school science investigations. Science Education, 92(5), 941-967. https://doi.org/10.1002/sce.20259 .

Wong, S. L., \& Hodson, D. (2009). From the horse's mouth: What scientists say about scientific investigation and scientific knowledge. Science Education, 93(1), 109-130.

Wong, S. L., \& Hodson, D. (2010). More from the horse's mouth: What scientists say about science as a social practice. International Journal of Science Education, 32(11), 1431-1463. https://doi.org/10. 1080/09500690903104465.

Woodcock, B. A. (2014). "The Scientific Method" as myth and ideal. Science \& Education, 23(10), 20692093. https://doi.org/10.1007/s11191-014-9704-z .

Yang, I., Oh, C., \& Cho, H. (2007). Development of the scientific inquiry process model based on scientist's practical work. Journal of the Korean Association for Research in Science Education, 27(8), 724-742.

Yayon, M., \& Scherz, Z. (2008). The return of the black box. Journal of Chemical Education, 85(4), 541. https://doi.org/10.1021/ed085p541 .

Zidny, R., \& Eilks, I. (2020). Integrating perspectives from indigenous knowledge and Western science in secondary and higher chemistry learning to contribute to sustainability education. Sustainable Chemistry and Pharmacy, 16, 100229. https://doi.org/10.1016/j.scp.2020.100229 .

Zidny, R., Sjöström, J., \& Eilks, I. (2020). A multi-perspective reflection on how indigenous knowledge and related ideas can improve science education for sustainability. Science \& Education, 29(1), 145-185. https://doi.org/10.1007/s11191-019-00100-x .

Publisher's Note Springer Nature remains neutral with regard to jurisdictional claims in published maps and institutional affiliations. 